A RCHIWA, BIBLIOTEKI

I MUZEA KOŚCIELNE 109 (2018)

https://doi.org/10.31743/abmk.2018.109.07

ANNA DYMMEL* - LUBLIN

PIOTR DYMMEL** - LUBLIN

\title{
BIBLIOTEKA KOLEGIUM JEZUITÓW W LUBLINIE I JEJ LOSY ${ }^{1}$
}

Zagadnienie biblioteki jezuitów lubelskich nie doczekało się dotychczas poważniejszej publikacji, nie licząc trzystronicowego opracowania ks. Ludwika Zalewskiego w jego pracy o bibliotece seminarium duchownego w Lublinie i bibliotekach klasztornych w diecezji lubelskiej i podlaskiej². W innej swojej pracy - monografii jezuitów w Lublinie autor ten całkowicie pominął dzieje biblioteki, chociaż z zachowanego rękopisu autorskiego wynika, że zamierzał o niej też nieco napisać ${ }^{3}$. W rezultacie nasza wiedza na temat biblioteki jezuitów lubelskich jest daleko niepełna i na pewno nie odpowiada jej znaczeniu i roli, jaką miała w życiu intelektualnym klasztoru i miasta. Nie była oczywiście jedyną biblioteką klasztorną w Lublinie, ale z blisko 5.000 tytułów w XVIII w. należała do największych, ustępując tylko miejsca bibliotece lubelskich dominikanów, która w tym samym czasie była przeszło dwukrotnie większa.

W okresie prawie dwuwiekowej obecności w Lublinie, jezuici posiadali trzy ośrodki, w wyposażeniu których istotne miejsce zajmowała biblioteka. Najważ-

* Anna Dymmel - dr hab. bibliologii i informatologii; kierownik Zakładu Kultury Informacyjnej i Czytelnictwa UMCS; e-mail: a.dymmel@poczta.umcs.lublin.pl

** Piotr Dymmel - dr historii; dyrektor Archiwum Państwowego w Lublinie; e-mail: pdymmel@lublin.ap.gov.pl

${ }^{1}$ Artykuł powstał w ramach „Narodowego Programu Rozwoju Humanistyki” nr 11.H 110212 80 (Dziedzictwo kulturowe po klasztorach skasowanych na ziemiach dawnej Rzeczypospolitej oraz na Ślasku w XVIII i XIX w.: losy, znaczenie, inwentaryzacja), finasowanego przez Ministerstwo Nauki i Szkolnictwa Wyższego.

${ }^{2}$ L. Zalewski, Biblioteka seminarium duchownego w Lublinie i biblioteki klasztorne $w$ diecezji lubelskiej i podlaskiej, Warszawa 1926, s. 242-245.

${ }^{3} \mathrm{~W}$ monografii poświęconej jezuitom w Lublinie ks. Zalewski pominął w zasadzie część poświęconą bibliotece - zob. L. Zalewski, Katedra i jezuici w Lublinie, cz. 1, Lublin 1947. W jego spuściźnie znajduje się kilkustronicowy, pisany na maszynie, tekst poświęcony bibliotece, który być może miał stanowić część monografii lub osobne opracowanie - Wojewódzka Biblioteka Publiczna im. Hieronima Łopacińskiego w Lublinie (dalej: WBPHŁ), sygn. 2160 I (dalej: Zalewski, Biblioteka). 
niejszym z nich było oczywiście założone przy kościele śś. Jana Chrzciciela i Jana Ewangelisty kolegium ze szkołą, działające do czasu kasaty, drugim z kolei była rezydencja lubelskich jezuitów w Chodlu przy kościele Matki Boskiej Loretańskiej, będąca w ich posiadaniu także do kasaty zakonu. Trzecim ośrodkiem było seminarium przy kolegiacie św. Michała w Lublinie, pozostające w latach 1675-1760 pod zarządem rektora kolegium jezuitów lubelskich. Księgozbiory tych trzech ośrodków składają się na pojęcie bibliotek jezuitów lubelskich. Można ich dzieje badać i opisywać łącznie w ramach szerszego zjawiska kultury intelektualnej i duchowej klasztoru, można też każdy z tych księgozbiorów traktować oddzielnie, podkreślając ich związek z miejscem i pełnionymi funkcjami przez poszczególne ośrodki. W niniejszym artykule uwaga zostanie skoncentrowana, zgodnie z tytułem, na bibliotece kolegium jezuitów w Lublinie ${ }^{4}$.

\section{1. Źródła i badania}

Stan źródeł do dziejów bibliotek jezuickich w Lublinie jest niejednolity. Ogólnie można powiedzieć, że dokumentacja źródłowa wytworzona przez jezuitów lubelskich jest dość uboga i w dodatku rozproszona, co w jakiejś mierze dotyczy także ich bibliotek, tym niemniej sytuacja jest bardziej zróżnicowana i wymaga indywidualnego podejścia. W badaniach nad dziejami bibliotek najbardziej pożądanym źródłem jest sam księgozbiór, który bezpośrednio informuje nas o zawartości, organizacji, sposobach, tempie gromadzenia i wielu innych istotnych aspektach ich dziejów. W przypadku likwidacji bibliotek jezuitów lubelskich i ich znacznego rozproszenia, możliwości poznania dawnego księgozbioru na podstawie zachowanego w całości lub większego fragmentu zbioru są bardzo ograniczone. W tej sytuacji na znaczeniu zyskują różnego rodzaju źródła o charakterze inwentaryzacyjnym, które rejestrują stan księgozbiorów w momencie ich tworzenia. Należą do nich katalogi, rejestry i inne spisy, które postanowiono sporządzić w określonych okolicznościach, zawsze wartych bliższego poznania. Niestety do naszych czasów nie zachowały się żadne katalogi i inwentarze biblioteki jezuitów w Lublinie, chociaż takie, z uwagi na obowiązek nakładany przez przepisy zakonne, musiały niewątpliwie być prowadzone ${ }^{5}$. O ich istnieniu świadczą też noty proweniencyjne na zachowanych egzemplarzach, które informują o wpisywaniu książek do katalogu.

W swoim krótkim szkicu ks. Zalewski przywoływał podstawowe źródło do dziejów biblioteki jezuitów lubelskich, którym była lustracja kościoła i kolegium

\footnotetext{
${ }^{4}$ Księgozbiory seminaryjne miały dużą niezależność w stosunku do pozostałych zbiorów kolegium, chociaż podlegały przełożonym domu zakonnego - L. Grzebień, Organizacja bibliotek jezuickich $w$ Polsce od XVI do XVIII wieku, Kraków 2013, s. 65. O bibliotece seminarium lubelskiego zob. tamże, s. 66-67; Zalewski, Biblioteka seminarium, s. 20-29; L. Piechnik, Seminaria diecezjalne w Polsce prowadzone przez jezuitów od XVI do XVIII wieku, Kraków 2001, s. 250-252.

${ }^{5}$ Grzebień, Organizacja bibliotek, s. 128-131. Na temat kolegium lubelskiego zob. P. Kochanowicz, Inwentarze bibliotek jezuickich 1570-1820. Próba rekonstrukcji, w: Librorum amatori. Ksiega pamiątkowa ofiarowana ks. Czestawowi Michalunio SJ na 50-lecie ofiarnej pracy w Bibliotece Filozoficznej Towarzystwa Jezusowego w Krakowie, red. A.P. Bieś SJ, Kraków 2004, s. $163-165,170$.
} 
jezuickiego sporządzona w 1773 r. po kasacie zakonu. Jej twórcy działający z ramienia Komisji Edukacji Narodowej zatytułowali ją Lustratio Ecclesiae collegii Lublinensis S. I. cum specificatione tam ecclesiae quam collegii infecta ao $1773^{6}$. Została sporządzona przez lustratorów Kajetana Jackowskiego, podczaszyca kijowskiego i Tomasza Poniatowskiego, miecznikowicza lubelskiego, działających zgodnie z instrukcją KEN. W dniu 16 listopada 1773 r. przystąpili do opisania „Collegji, Kościoła, Rezydencji, Kamienic, dóbr, sreber, apparencji, i wszelkich in genere et specie rzeczy w jakim stanie zostawione są". Jeszcze przed drugą wojną światową lustracja ta znajdowała się w Archiwum Głównym Akt Dawnych, w zespole Akta Komisji Edukacyjnej ${ }^{7}$. Została jednak zniszczona razem $\mathrm{z}$ większością akt. Inny egzemplarz tej lustracji lub jej kopia znajdowały się do czasów drugiej wojny światowej w Bibliotece Uniwersytetu Warszawskiego, niestety dziś należą do zaginionych lub zniszczonych zbiorów ${ }^{8}$.

Pomimo bardzo złego zachowania źródeł do dziejów bibliotek lubelskich jezuitów, czy ich przeszłości w ogóle, dotychczas nie zwrócono uwagi na odpis wspomnianej lustracji zachowany w spuściźnie po ks. L. Zalewskim. W trakcie pracy nad monografią jezuitów w Lublinie w latach 30. ubiegłego stulecia, zamówił on w AGAD pełny odpis lustracji, dzięki któremu zachowało się do dziś podstawowe źródło do poznania kultury materialnej, religijnej i intelektualnej lubelskich jezuitów nie tylko w momencie kasaty zakonu, ale też i wcześniej ${ }^{9}$. Ma on też szczególne znaczenie do badań nad historią ich bibliotek, czy szerzej różnych aspektów kultury książki. W wielu miejscach lustracji zawarte są informacje dotyczące książki w klasztorze, na s. 54-171 jej oryginału znajdował się opis zawartości biblioteki kolegium zatytułowany Spisanie ksiag w bibliotece wyższej będacych. Niestety w odpisie brakuje zapowiadanego spisu, co więcej, nie odnaleziono go w całej znanej spuściźnie po ks. Zalewskim ${ }^{10}$.

${ }^{6}$ Zalewski, Biblioteka seminarium, s. 243.

${ }^{7}$ Tamże, przyp. 2 (tu podano błędną informację, jakoby rękopis miał znajdować się w zbiorach APL, czyli Archiwum Państwowego w Lublinie, zamiast AGAD - Archiwum Głównego Akt Dawnych); por. Zalewski, Katedra, s. 6.

${ }^{8}$ Rękopis w Bibliotece Uniwersytetu Warszawskiego (dalej: BUW) został opisany pod tytułem Lustracje Kollegium Jezuickiego w Lublinie po zniesieniu zakonu, r. 1773. Oznaczony numerem inwentarzowym 574, występował pod sygnaturą 4.4.25. Należał do Archiwum Komisji Edukacji Narodowej - zob. H. Kozerska, Straty w zbiorze rękopisów Biblioteki Uniwersyteckiej w Warszawie w czasie I i II wojny światowej, Warszawa 1960, s. 37. Niezrozumiała wydaje się informacja, że katalog zawierał pobieżny spis książek, które do 1939 r. znajdowały się w BUW - Kochanowicz, Inwentarze bibliotek jezuickich 1570-1820. Próba rekonstrukcji, s. 170. Zawierał on spis wszystkich książek z biblioteki lubelskiego kolegium, a nie tylko tych z BUW.

${ }^{9}$ Odpis zachował się w spuściźnie po ks. L. Zalewskim w WBPHŁ w Lublinie - sygn. 2160 IV k. 1166-1500. Nosi tytuł Lustracja Kolegium lubelskiego księży jezuitów przez Kajetana Jackowskiego podczaszyca kijowskiego i Tomasza Poniatowskiego miecznikowicza lubelskiego rozpoczęta 16 listopada 1773 (345 str. z planami) - (dalej: Lustracja).

${ }^{10} \mathrm{~W}$ odpisie Lustracji zachował się tytuł Spisanie ksiag w Bibliotece wyższej będacych, jednak brakuje samego spisu książek - Lustracja, s. 1243. Zastanawia brak tego spisu. Trudno przypuszczać aby ks. L. Zalewski zrezygnował z otrzymania odpisu tej partii Lustracji, tym bardziej, że zagadnienie biblioteki jezuickiej należało do ważniejszych obszarów jego badawczych zainteresowań. 
Pomimo braku konsygnacji książek należących do kolegium, interesująca nas Lustracja z 1773 r. dostarcza wielu ważnych, wręcz unikalnych informacji o bibliotekach lubelskich jezuitów, co czyni z niej podstawowe źródło do tego zagadnienia. W zachowanym przekazie ks. Zalewskiego znajduje się opis pomieszczeń biblioteki kolegium jezuickiego, struktura i ogólna wielkość księgozbioru biblioteki, spis książek, które były poza biblioteką na wyposażeniu klasztoru i kościoła, w końcu spis księgozbioru znajdującego się w rezydencji jezuitów w Chodlu ${ }^{11}$.

Brak rozpoznania źródeł, rozproszenie księgozbioru i niedostatek badań, nie pozwolił dotychczas na choćby pobieżne opracowanie dziejów biblioteki jezuitów lubelskich. Dysponujemy zaledwie pojedynczymi informacjami, które bardziej pokazują i uświadamiają potrzeby badawcze niż tworzą nawet najbardziej ogólny obraz jej historii i zbiorów. Większość tych informacji zawdzięczamy ks. L. Zalewskiemu, który - jak już wspomniano powyżej - przygotował kilkustronicowy, zachowany w maszynopisie, tekst poświęcony bibliotece. Być może miał stanowić część monografii o jezuitach w Lublinie lub osobne opracowanie.

\section{Początki biblioteki i gromadzenie książek}

Początki biblioteki jezuitów w Lublinie sięgają czasów założenia samego klasztoru, którego fundatorem był Bernard Maciejowski, podówczas kanonik krakowski i dziekan gnieźnieński, a po święceniach w 1586 r. tymczasowy administrator diecezji łuckiej, niedługo później biskup łucki. W latach 80. XVI w. zapisał on jezuitom część dóbr rodowych jako uposażenie kolegium lubelskiego. Jego budowę rozpoczęto w 1585 r. $^{12}$ Rok później kolegium rozpoczęło działalność, a ponieważ nie zostały jeszcze ukończone prace budowlane nowego budynku szkolnego, nauka była prowadzona przez kilka lat prawdopodobnie w kamienicy Tęczyńskich, którą jezuici zajmowali już wcześniej ${ }^{13}$. Biblioteka klasztorna była zapewne tworzona od samego początku przybycia jezuitów do Lublina. W odróżnieniu od kilku innych domów zakonnych nic nie wiadomo aby jej zalążkiem były książki podarowane przez fundatora kolegium. Jednak już w 1584 r. Kasper

Nic też nie wiadomo o rozproszeniu jego naukowej spuścizny, które mogłoby tłumaczyć pozostawienie spisu książek poza materiałami przekazanymi do WBPHŁ w Lublinie, gdzie ta spuścizna się znajduje. W odpisie widoczna jest wyraźna luka w foliacji oryginału Lustracji, po k. 54 następuje k. 173. Jednocześnie nie ma przerwy w paginacji sporządzonej już w WBPHŁ, według której k. 54 odpowiada s. 1243, a k. 173 s. 1245 (s. 1244 została przestawiona i odnosi się do k. 342 oryginału). Na razie nie można w sposób satysfakcjonujący wyjaśnić tej luki.

${ }^{11}$ Lustracja z 1773 r. pozwala poznać dwie biblioteki jezuickie: kolegium w Lublinie i rezydencji w dobrach chodelskich. Trzecia biblioteka lubelskich jezuitów związana z seminarium przy kolegiacie św. Michała posiada katalog, na podstawie którego w 1760 r. książki zostały przekazane do biblioteki księży misjonarzy, którzy odtąd mieli zajmować się kształceniem kleryków. Katalog ten jest obecnie przechowywany w Bibliotece Narodowej w Warszawie, sygn. III 6878 - zob. Katalog rękopisów Biblioteki Narodowej, t. 7, red. K. Muszyńska, Warszawa 1969 s. 343.

${ }^{12} \mathrm{O}$ genezie i uposażeniu kolegium jezuickiego w Lublinie zob. Zalewski, Katedra i jezuici, s. 9-14.

${ }^{13}$ Tamże, s. 49-58. 
Chronovius z Tarnowa przekazał lubelskim jezuitom liczne dzieła, przyczyniając się do powstania klasztornej biblioteki ${ }^{14}$.

Podstawową kwestią funkcjonowania bibliotek zakonu jezuitów stanowiło finansowanie ich działalności, a zwłaszcza powiększania księgozbioru. Ważną rolę w rozwoju bibliotek jezuickich odegrało opublikowanie w 1599 r. ostatecznej wersji Ratio studiorum - ustawy szkolnej, która tworzyła podstawy działalności edukacyjnej i naukowej jezuitów na prawie dwa stulecia ${ }^{15}$. Jej publikacja jest równoczesna z pierwszymi latami istnienia lubelskiego kolegium, można zatem powiedzieć, że wyznaczała też zasady prowadzenia zakonnej biblioteki od samego początku działalności. Zawierała ogólną regułę dotyczącą utrzymywania bibliotek, które były nierozerwalną częścią każdego kolegium. Nakazywano, aby każdy dom przeznaczył na potrzeby i rozwój biblioteki rocznie pewne fundusze $\mathrm{z}$ dóbr własnych kolegium lub $\mathrm{z}$ innych źródeł. Pieniędzy tych nie wolno było wydawać na inne cele ${ }^{16}$. Jeśli kolegium nie posiadało specjalnego uposażenia na cele biblioteczne, wówczas pieniądze pochodziły z uposażenia całego kolegium. Nie wiadomo, czy w kolegium lubelskim wydano jakieś dokładniejsze przepisy dotyczące funkcjonowania biblioteki, a zwłaszcza jej finansowania. Należało ono do tych placówek, które posiadało specjalne sumy zapisane na cele biblioteczne. Prawie do samej kasaty ogólne reguły Ratio studiorum były wystarczające dla prowadzenia bibliotek, chociaż coraz częściej zaczęły pojawiać się sygnały o niedostatecznych środkach finansowych na zakupy książek, co skazywało biblioteki na stagnację ${ }^{17}$. W 1763 r. generał zakonu ks. Wawrzyniec Ricci wydał polecenie aby kolegia większe, do których zaliczało się lubelskie, wydawały co najmniej $500 \mathrm{zł}$ rocznie na powiększenie księgozbioru biblioteki ${ }^{18}$.

Przepisy zakonne wpływały także na funkcjonowanie i rozwój biblioteki kolegium lubelskiego. Podstawowym obszarem jej działalności było gromadzenie i kształtowanie księgozbioru. Księgozbiór lubelski, podobnie jak w innych domach zakonnych, powstawał dzięki różnym źródłom pozyskiwania książek, do których należały głównie fundacje, dary, zakupy i produkcja własna. Trudno ocenić, który ze sposobów powiększania zbiorów przeważał w lubelskim kolegium, wydaje się jednak, że stałym źródłem były zakupy. Co najmniej od połowy XVII

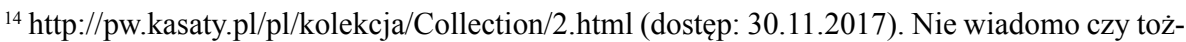
samy z Kasprem Chronoviusem, prepozytem radziejowskim, znanym m.in. z wpisu w Metryce Koronnej pod 1588 r. MK 135, k. 40v-41 [SKM IV, nr 43] - http://www.agad.gov.pl/pomoce/MK_135. xml. (dostęp: 30.11.2017).

${ }^{15}$ L. Piechnik, Powstanie i rozwój jezuickiej „Ratio studiorum” (1548-1599), Kraków 2003; tenże, , Ratio studiorum”: fundament działalności edukacyjnej i naukowej jezuitów, w: Wkład jezuitów do nauki i kultury w Rzeczypospolitej Obojga Narodów i pod zaborami, red. I. Stasiewicz-Jasiuk, Kraków-Warszawa 2004, s. 69-90.

${ }^{16}$ Ratio atque institutio studiorum SJ czyli ustawa szkolna Towarzystwa Jezusowego, red. K. Bartnicka, T. Bieńkowski, Warszawa 2000, s. 41. Por. Grzebień, Organizacja bibliotek, s. 24-25.

${ }^{17}$ Grzebień, Organizacja bibliotek, s. 93.

${ }^{18}$ Tamże, s. 93; S. Bednarski, Upadek i odrodzenie szkót jezuickich w Polsce. Studium z dziejów kultury i szkolnictwa polskiego, Kraków 1933, s. 83. Mniejsze kolegia obowiązane były na ten cel wydać 400 i 300 zł, małe domy, rezydencje i stacje misyjne po $200 \mathrm{zł}$. 
stulecia biblioteka posiadała specjalne sumy, którymi zarządzali rektorzy kolegium. Od ok. 1649 r. biblioteka otrzymuje zapis 1.500 złp z procentem $120 \mathrm{złp}$, a uposażenie znacznie wzrasta w latach 1690 i $1693^{19}$. Na przełomie XVII i XVIII w. o sumach zapisanych na cele biblioteczne spotykamy wzmianki w rezygnacjach rektorów, którzy zdawali sprawozdanie z gospodarki finansami kolegium, a przy tej okazji informowali także o wydatkach na bibliotekę. Rektor Rafał Taczanowski w ciągu swych rządów w latach 1699-1701 wydał na zakup książek 815 zł, które zostały wykazane w inwentarzu. Z jego osobą jest zapewne związany duży zakup książek do biblioteki domowej w 1699 r., który odnotowano krótko i rzeczowo: „Bibliotheca quoque domestica plurimis aucta libris noviter comparatis" ${ }^{20}$. Ks. Taczanowski ponadto zabezpieczył też inne fundusze na bibliotekę, zostawiając w gotówce 178 złp i u niejakiej Nosadyniowej 1.058 złp i 18 groszy procentu do odebrania ${ }^{21}$. Z kolei rektor Szczepan Szczaniecki w 1710 r. stwierdził w rezygnacji, że z pieniędzy bibliotecznych zostawił 118 złp w gotówce i 2.000 złp ulokowanych u Żydów na 10 procent. Podobnie, jak w poprzednim przypad$\mathrm{ku}, \mathrm{w}$ rezygnacji skrupulatnie zaznaczono, że książki zakupione do biblioteki są zapisane $\mathrm{w}$ inwentarzu ${ }^{22}$.

Ważnym źródłem pozyskiwania książek była ofiarność różnych darczyńców, którzy w postaci darów i legatów wzbogacali księgozbiór i przyczyniali się do rozwoju biblioteki. Znamy kilka przykładów hojności dobrodziejów, ale można przypuszczać na podstawie innych domów zakonnych w Rzeczypospolitej, że podobnych przypadków było znacznie więcej ${ }^{23}$. Przywołano już wcześniej książkowy dar Kaspra Chronoviusa z Tarnowa, leżący u początków biblioteki lubelskiego kolegium. Kolejne przykłady ofiarności można odnotować w całym XVII stuleciu. W 1606 r. Jan Koniecpolski, sędzia ziemski lubelski, w testamencie zapisał swoją bibliotekę lubelskim jezuitom ${ }^{24}$. Wzbogacił ją również ks. Hieronim Zahorowski, proboszcz w Kamionce koło Lubartowa, przekazując kolegium przed śmiercią w 1634 r. swój księgozbiór ${ }^{25}$. Niestety nie znamy zawartości tych księgozbiorów, można być jednak pewnym, że były raczej rezultatem zainteresowania ich właścicieli niż potrzeb edukacyjnych i naukowych jezuitów. Kolejne dary książek

${ }^{19} \mathrm{http}: / /$ pw.kasaty.pl/pl/kolekcja/Collection/2.html (dostęp: 30.11.2017).

${ }^{20}$ Archivum Romanum Societatis Iesu, Pol. 53 f. 56; cyt. za B. Lisiak, Proces przed Trybunatem Lubelskim $w$ sprawie książek Potockiego w bibliotece jezuitów lubelskich, w: Librorum amatori, Ksiega pamiątkowa ofiarowana ks. Czestawowi Michalunio SJ na 50-lecie ofiarnej pracy w Bibliotece Filozoficznej Towarzystwa Jezusowego w Krakowie, red. A.P. Bieś SJ, Kraków 2004, s. 130.

${ }^{21}$ Zalewski, Biblioteka, k. 213.

${ }^{22}$ Tamże.

${ }^{23} \mathrm{O}$ roli darczyńców w kształtowaniu bibliotek jezuickich zob. Bednarski, Upadek i odrodzenie szkót jezuickich w Polsce, s. 82-83; L. Grzebień, Dzieje kulturalne jezuitów toruńskich (1596-1996), w: Jezuici w Toruniu 1596-1996, red. K. Maliszewski, W. Rozynkowski, Torun 1997, s. 80-81; W. Graczyk, J. Kwiatkowski, Jezuici w Płocku 1611-1773, Warszawa 2002, s. 45-53, 64-67; S. Kościelak, Jezuici w Gdańsku od drugiej połowy XVI do końca XVIII wieku, Kraków 2003, s. 174-175; Grzebień, Organizacja bibliotek, s. 78-82.

${ }^{24}$ Zalewski, Biblioteka, k. 214.

${ }^{25}$ Tamże. 
zostały przekazane kolegium lubelskiemu w 1658 i $1677 \mathrm{r}^{26} \mathrm{~W}$ tym miejscu należy też wspomnieć o złożonym w kolegium lubelskim depozycie książek, w sprawie którego w 1701 r. toczył się proces w lubelskim Trybunale Koronnym. Książek musiało być sporo, skoro wypełniały dziewięć beczek ${ }^{27}$. Jezuici początkowo opierali się przed zwrotem zdeponowanych książek, w tym celu prawdopodobnie oznaczyli wszystkie książki, które nie miały znaku przynależności, swoją odręcznie sporządzoną notą własnościową: „Col. Soc. Jesu 1701”. Ostatecznie sprawa zakończyła się polubownie: część książek zwrócono Potockim, a pozostała część wzbogaciła bibliotekę kolegium lubelskiego ${ }^{28}$.

Niemałą rolę w powiększaniu bibliotek odgrywały też dary samych autorów jezuickich, którzy ofiarowywali swoim współbraciom i domom zakonnym własne dzieła. Podobnie było zapewne i w Lublinie, ale skalę tego zjawiska będzie można ocenić dopiero po rozpoznaniu dedykacji autorskich. Przykładem jest zachowany do dziś egzemplarz z dedykacją znanego pisarza polemicznego z początku XVIII w. Jerzego Gengella podarowany bibliotece kolegium w Lublinie ${ }^{29}$.

Innym źródłem nabytków biblioteki była własna produkcja pisarska i drukarska. W Ratio studiorum nakazano składać do biblioteki i tam przechowywać rękopisy z dialogami, mowami, wierszami i innymi cenniejszymi utworami, których autorami byli jezuici ${ }^{30}$. $Z$ braku informacji trudno ocenić skalę i tempo gromadzenia rękopiśmiennych materiałów produkcji własnej w kolegium lubelskim, zapewne musiała być porównywalna z większymi ośrodkami, ale na pewno dużo mniejsza od Krakowa, gdzie specjalnie wydzielony księgozbiór rękopisów liczył

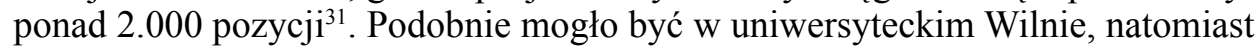
w Lublinie porównując liczbę rękopisów do produkcji własnej drukarni można rękopiśmienny zbiór szacować na 600 do 1.000 pozycji. Nie wiadomo, czy został on wliczony w ogólną liczbę książek opisanych w lustracji, czy też był wydzielony i spisany osobno. W spisie treści Lustracji nie wspomina się o osobnej grupie rękopisów, chociaż w opisach pozostałości po kolegium zaznaczano rękopiśmienną formę niektórych książek. Zapewne do rękopisów należy też zaliczyć liczne rejestry wymienione w Lustracji, które faktycznie miały charakter archiwalny.

${ }^{26} \mathrm{http}: / /$ pw.kasaty.pl/pl/kolekcja/Collection/2.html (dostęp: 30.11.2017).

${ }^{27}$ „Novem dolia libri impleverant” - B. Lisiak, Proces przed Trybunatem Lubelskim w sprawie książek Potockiego, s. 131 (dodatek źródłowy).

${ }^{28}$ Tamże, s. 130. W bibliotece jezuitów istotnie pozostały książki z odręcznym dopiskiem „Col. Soc. Jesu 1701”. W XIX w. były przechowywane w katedrze lubelskiej, w okresie międzywojennym przeszły do Biblioteki „Bobolanum” w Lublinie, a teraz znajdują się w Bibliotece „Bobolanum” w Warszawie. Ciekawe, że do Potockich także wróciły książki oznaczone notą kolegium jezuitów w Lublinie. Do dziś w Bibliotece Wilanowskiej znajduje się 80 książek z notą: „Col. Soc. Jesu 1701” - J. Rudnicka, Biblioteka Wilanowska. Dwieście lat jej dziejów (1741-1932), Warszawa 1967, s. 33.

${ }^{29}$ Grzebień, Organizacja bibliotek, s. 81.

${ }^{30}$ Ratio studiorum, s. 46 ,[Rektor] Niech dba, by przestrzegane było to, co jest zawarte w regułach prefekta biblioteki o włączeniu do spisu tego wszystkiego, co Nasi pisali i wystawiali publicznie w kolegium lub poza kolegium. Chodzi o dialogi, mowy, wiersze i inne tego rodzaju utwory" - zob. Zalewski, Biblioteka, k. 213; Grzebień, Organizacja bibliotek, s. 85.

${ }^{31}$ Grzebień, Organizacja bibliotek, s. 90-91. 
W znacznym stopniu i bez dodatkowych kosztów, jezuici powiększali biblioteki książkami wydawanymi na własny użytek lub we własnych drukarniach. Druki przeznaczone na własny użytek, takie jak: katalogi, reguły i instrukcje zakonne, nie ukazywały się w sprzedaży, lecz prosto z drukarni były rozsyłane do poszczególnych placówek. Podobnie kolportowano podręczniki, opisy działalności misyjnej zakonu, roczniki wszystkich prowincji i listy z terenów misyjnych ${ }^{32}$. Dla rozwoju biblioteki kolegium lubelskiego istotne znaczenie miało uruchomienie własnej drukarni w Lublinie. W okresie jej działalności w latach 1683-1773, wydrukowano ponad 600 publikacji, które zasiliły zbiory biblioteki ${ }^{33}$. W zależności od szacunkowych obliczeń mogły stanowić od 6\% do $10 \%$ całego księgozbioru. Warto wspomnieć, że w kolegium lubelskim znajdowały się dwa specjalne pomieszczenia, w których przechowywano książki przeznaczone do sprzedaży i do oprawy (in crudo) ${ }^{34}$. W Lustracji są wymienione dwa rejestry Regestr Xiag in crudo, czyli spis książek wydrukowanych, ale jeszcze nie oprawionych i Regestr Xiag oprawnych do przedania, a więc rejestr książek już gotowych do sprzeda$\dot{z} y^{35}$. Według ks. Zalewskiego pierwszy obejmował 90 dzieł w 29.804 egzemplarzach, a drugi - 109 dzieł w 1.069 tomach $^{36}$.

Wśród różnych źródeł i sposobów pozyskiwania książek ks. Zalewski zwrócił uwagę na nieformalny przepływ książek, przenoszonych przez zakonników. Przepisy nie pozwalały zakonnikom przy przenoszeniu się do innej placówki, zabierać ze sobą książek ze zbiorów bibliotecznych. Wypadki takie musiały zdarzać się jednak często, bowiem w wielu bibliotekach można spotkać książki z innych klasztorów. Jezuici lubelscy posiadali książki z domów zakonnych położonych na terenie całej Rzeczpospolitej, a niekiedy także poza jej granicami ${ }^{37}$. Zapewne taką drogę odbyła zachowana do dziś książka z superekslibrisem Jana Leśniowolskiego, podczaszego lwowskiego, która z kolegium jezuitów w Brześciu trafiła do Lublina $^{38}$.

\section{Biblioteka wspólna}

W przypadku książnic jezuickich w zasadzie można mówić o systemie bibliotek, na który składały się różne ich rodzaje i wzajemne zależności zachodzące między nimi. Z podobną sytuacją mamy do czynienia w przypadku biblioteki jezuitów lubelskich, która składała się z księgozbioru domowego, zwanego też

${ }^{32}$ Tamże, s. 87-89.

${ }^{33}$ E.A. Żukowska, Powstanie i działalność drukarni jezuickiej w Lublinie, w: Lublin a książka, cz. 2: Centrum i peryferie, red. A. Krawczyk, Lublin 2011 s. 244. O wydanych w drukarni jezuitów drukach zob. I. Dziok-Strelnikowa, Bibliografia starych druków lubelskich 1630-1800, Lublin 1997.

${ }^{34}$ Lustracja, s. 1168, 1189-1190.

${ }^{35}$ Tamże, s. 1520.

${ }^{36}$ Zalewski, Biblioteka seminarium, s. 244.

${ }^{37}$ Tamże, k. 214.

${ }^{38}$ Tamże, s. 34; A. Sułek, Ekslibris i superekslibris XVIII w. w zbiorach Biblioteki Metropolitalnego Seminarium Duchownego w Lublinie, „Bibliotekarz Lubelski”, 41 (1996) s. 31. 
wspólnym oraz bibliotek i księgozbiorów specjalnych ${ }^{39}$. Podstawowe znaczenie w tym systemie bibliotecznym miała biblioteka wspólna, która wyróżniała się odpowiednim pomieszczeniem, wielkością i zróżnicowaniem księgozbioru oraz organizacją i zasadami działania. Jej istnienie było podyktowane obowiązującymi przepisami prawa zakonnego, które nie pozwalały na posiadanie książek przez poszczególnych zakonników, bez specjalnego zezwolenia.

\subsection{Pomieszczenie}

Dzięki Lustracji z 1773 r. znamy lepiej usytuowanie, wygląd i sposób urządzenia pomieszczenia biblioteki wspólnej, w lubelskim kolegium. Trzeba przypomnieć, że biblioteki jezuickie nie były przeznaczone dla uczniów, lecz dla profesorów i kaznodziejów, dlatego nigdy nie były umieszczane w budynku szkolnym, ale zawsze w domu zakonnym objętym klauzurą ${ }^{40}$. Podobnie było w Lublinie. Do końca XVII w. biblioteka mieściła się w rogu starego kolegium, dopiero po rozbudowie za ks. Rafała Taczanowskiego (1699-1701) została „ex antiquo angulo in capaciorem locum" przeniesiona do nowego budynku ${ }^{41}$. Odtąd aż do kasaty zajmowała obszerną salę narożną w południowo-zachodniej części budynku kolegium. Umieszczona była na pierwszym piętrze i podobnie do innych największych polskich kolegiów (Kraków, Grodno, Ostróg, Połock, Wilno) znajdowała się nad refektarzem, czyli jadalnią ${ }^{42}$.

Zgodnie z powszechnym zwyczajem, w lubelskim kolegium nie było podziału na magazyn i lektorium, cały księgozbiór znajdował się w jednym pomieszczeniu. Była to wielka i wysoka na dwa piętra sala, oświetlona podwójnym rzędem okien, z których cztery wychodziły na południe w stronę Żmigrodu, osiem zaś w kierunku zachodnim w stronę Bramy Krakowskiej. Pod górnymi oknami biegła galeryjka umożliwiająca dostanie się do wyższych półek.

Jezuici starali się, aby w myśl przepisów zakonnych, biblioteka pod względem wyglądu była najpiękniej urządzonym pomieszczeniem, zaraz po świątyni. W polskich domach jezuickich dopiero w XVIII w., w czasach odradzania się kulturalnego jezuitów, można zaobserwować większą dbałość o urządzenie, jak to określił Jerzy Paszenda, „ozdobnych bibliotek”. Książnice te wyróżniały się swoim zewnętrznym wystrojem i bogatymi dekoracjami. Nie było to jednak zjawisko powszechne, miało ono miejsce w głównych miastach Rzeczypospolitej i większych kolegiach. Na terenie czterech prowincji tworzących asystencję polską było zaledwie dziewięć ozdobnych bibliotek (Kraków, Warszawa, Wilno Aka-

${ }^{39} \mathrm{O}$ rodzajach bibliotek jezuickich zob. Grzebień, Organizacja bibliotek, s. 38-44. Autor ten używa terminu „biblioteki i księgozbiory specjalistyczne”, w tym miejscu wolimy zastąpić go terminem ,specjalne” zwracając uwagę nie tyle na zakładany jednorodny charakter księgozbioru, ile na jego użytkowników.

${ }^{40}$ J. Paszenda, Pomieszczenia biblioteczne u jezuitów polskich, w: Librorum amatori, Księga pamiatkowa ofiarowana ks. Czestawowi Michalunio SJ na 50-lecie ofiarnej pracy w Bibliotece Filozoficznej Towarzystwa Jezusowego w Krakowie, red. A.P. Bieś SJ, Kraków 2004, s. 111.

${ }^{41}$ Zalewski, Biblioteka, k. 215.

${ }^{42}$ Paszenda, Pomieszczenia, s. 114; Grzebień, Organizacja bibliotek, s. 116-117. 
demia, Grodno, Gdańsk, Poznań, Wilno Collegium Novum, Połock), wśród nich znajdowało się kolegium w Lublinie ${ }^{43}$.

Przed połową XVIII w. biblioteka jezuitów lubelskich nie wyróżniała się swoim wyglądem i organizacją. Kasper Niesiecki w liście do Józefa Andrzeja Załuskiego z 1732 r. do najlepiej zorganizowanych i urządzonych bibliotek jezuickich zaliczył książnice we Lwowie, Krakowie i Poznaniu, Lublina nie wymienił w tej grupie $^{44}$. Dopiero na początku 2. połowy XVIII w. nastąpiła zasadnicza zmiana w tym stanie, gdy w latach 1753-1760 biblioteka lubelska została bogato wyposażona i otrzymała wspaniałe dekoracje, które na długo zapadały w pamięci ją oglądających. Odnowienie i ozdobienie lubelskiej biblioteki było możliwe m.in. dzięki hojności byłego jezuity Antoniego Kiełczewskiego, pochodzącego z zamożnej rodziny, która posiadała dobra niedaleko Lublina ${ }^{45}$. Na bogate wyposażenie i wystrój zwrócili uwagę lustratorzy, którzy inwentaryzując pozostałości po kolegium jezuickim, niejednokrotnie wyrażali swoje estetyczne opinie.

Uwagę lustratorów przyciągnęły podwójne drzwi sosnowe prowadzące do biblioteki, które były osadzone na mosiężnych zawiasach, a ich odrzwia były pociągnięte pokostem i inkrustowane dębem w kwiaty. Nad drzwiami znajdował się przygotowany kartusz na herb, może herb hojnego darczyńcy. Podłoga dębowa była „w różne sztuki wysadzana”. Dookoła sali stały dębowe szafy „pięknej roboty” pokostowane i inkrustowane dębem oraz „sztukami różnymi snycerską robotą, wyzłacanymi tudzież chińskiem malowaniem przyozdobione". Ponadto w skrzyni znajdowało się wiele sztuk różnych rżniętych dla ozdobienia biblioteki, pod pozłotę gruntowanych.

W bibliotece znajdowały się tylko potrzebne do korzystania z niej sprzęty. Najważniejszą częścią wyposażenia były oczywiście szafy na książki, które jak już wspomniano, stały dookoła sali. Szczególną uwagę zwracały dwie pomalowane na czarno szafki drewniane z drzwiczkami podwójnymi na zawiasach żelaznych i zamykane na haczyki. W jednej z nich przechowywano rejestr zmarłych zakonników, w drugiej księgę z nazwiskami fundatorów lubelskiego kolegium. Po obydwu stronach sali przy ścianie umieszczono ławki „stolarskiej roboty dla siedzenia przysposobione". Prawdopodobnie na środku znajdował się duży stół sosnowy z czterema szufladami, a gdzieś obok niego cztery stoły sosnowe mniejsze na podnóżkach toczonych, które służyły do pracy z książkami. Do szaf wyżej położonych dostęp ułatwiały będące na wyposażeniu jeden stopień drewniany $i$ jedna drabina drewniana. W bibliotece była też skrzynka sosnowa z przykryciem na żelaznych zawiasach.

Ozdobny charakter biblioteki nie mógł przesłonić faktu, że jej stan budowlany nie był najlepszy i wymagała ona pilnego remontu. Nie uszło uwagi lustratorów,

${ }^{43}$ Paszenda, Pomieszczenia, s. 112-118.

${ }^{44}$ L. Grzebień, Józef Andrzej Zatuski a jezuici, „Roczniki Teologiczno-Kanoniczne”, 31 (1984) z. 4, s. 63-64. Ostatnio list ten wydał K. Niesiecki, List Kaspra Niesieckiego SJ do Józefa Andrzeja Zatuskiego, w: Librorum amatori. Księga pamiatkowa ofiarowana ks. Czesławowi Michalunio SJ na 50-lecie ofiarnej pracy w Bibliotece Filozoficznej Towarzystwa Jezusowego w Krakowie, red. A.P. Bieś SJ, Kraków 2004, s. 133-135.

${ }^{45}$ Lustracja, s. 1183. Por. Bednarski, Upadek i odrodzenie szkót jezuickich w Polsce, s. 83. 
że mury biblioteczne były „,znacznie porysowane, sklepienie do upadku bliskie”. Sami jezuici zamierzali przystapić do ich naprawy, w tym celu przygotowano już ankry, a koszty remontu obliczono na 3.000 złp. ${ }^{46}$ Do prac budowlanych jednak jezuici już nie zdążyli przystąpić, a po kasacie pomieszczenie biblioteki wraz z całym południowo-zachodnim skrzydłem gmachu kolegium zaczęło popadać w coraz większą ruinę, aż ostatecznie na początku XIX w. zostało rozebrane ${ }^{47}$.

\subsection{Księgozbiór}

Brak zachowanych inwentarzy nie pozwala w pełnym zakresie rozpoznać zbioru książek znajdujących w bibliotece lubelskiego kolegium. Jej zawartość jest właściwie możliwa do poznania tylko na drodze rekonstrukcji księgozbioru, w oparciu o badania proweniencyjne zachowanych egzemplarzy książek. Jak każde takie badanie, jest to droga długa i żmudna, często jednak przynosząca satysfakcjonujące wyniki. Dysponujemy już pewnymi informacjami, które dają ogólny obraz biblioteki, chociaż nie zawsze są one jednakowe. Rozbieżności istnieją już przy podawaniu informacji o wielkości jej księgozbioru. L. Zalewski podał, że biblioteka jezuitów w chwili kasaty posiadała łącznie 4.876 książek (dzieł) w 7.415 tomach, podczas gdy Stanisław Bednarski obliczył ją na 7.770 dzieł ${ }^{48}$. Wielkości te byłyby zbliżone, gdyby przyjąć, że ten drugi autor pisząc o dziełach miał na myśli tomy, w przeciwnym razie trudno wytłumaczyć rażącą różnicę prawie 3.000 książek (dzieł). Przypuszczenie to jest jednak niemożliwe do zweryfikowania $^{49}$. Z kolei L. Grzebień, bibliotekę wspólną jezuitów lubelskich zalicza do rzędu placówek o najbogatszych zbiorach, które posiadały około 10.000 tomów. Podobne liczebnie księgozbiory posiadały kolegia w Braniewie, Jarosławiu, Krakowie, Nieświeżu, Poznaniu, Warszawie i Wilnie ${ }^{50}$.

W przywoływanej już wielokrotnie Lustracji z 1773 r., na końcu znajduje się spis zawartości tego dokumentu, w którym w części poświęconej bibliotece zostały wymienione nazwy jej działów ${ }^{51}$. Dzięki niemu wiadomo jak wyglądał układ księgozbioru. Książki były podzielone na 38 działów, głównie według trzech powszechnie wówczas stosowanych kryteriów porządkujących księgozbiory: tematyki, języka i formatu. Nazwy tych działów zostały podane także przez ks. L. Zalewskiego, jednak z pewnymi różnicami w ich brzmieniu, a nawet samego faktu

${ }^{46}$ Lustracja, sygn. 2160 IV, s. 1516 „Expens na utrzymanie zabudowania Collegii”.

${ }^{47}$ Losy zabudowań kolegium jezuickiego po kasacie zakonu opisuje Zalewski, Katedra, s. 136147.

${ }^{48}$ Zalewski, Biblioteka seminarium, s. 244; Bednarski, Upadek i odrodzenie szkót jezuickich w Polsce, s. 83.

${ }^{49}$ Być może różnice $\mathrm{w}$ obliczeniach wielkości księgozbioru wynikały $\mathrm{z}$ odmiennego sposobu liczenia. Należy także zwrócić uwagę, że L. Zalewski korzystał z egzemplarza Lustracji przechowywanego w AGAD, zaś S. Bednarski z rękopisu należącego do BUW, ale nie wiadomo, czy one między sobą się różniły.

${ }^{50}$ Grzebień, Organizacja bibliotek, s. 104.

${ }^{51}$ Lustracja, s. 1518-1519. Spis poszczególnych działów jest poprzedzony tytułem: Spisanie Xiag w bibljotece wyższej będacych. W oryginalnej wersji Lustracji spis książek biblioteki kolegium jezuickiego w Lublinie mieścił się na kartach 54-171. 
występowania $^{52}$. Nie zostały przez niego wydzielone książki z uwagi na ich format, nie uwzględnił też w osobnej grupie książek medycznych przeniesionych do biblioteki z apteki klasztornej, podał natomiast bardziej szczegółową informację o książkach wypożyczonych do pomieszczeń nauczycieli. Autor ten dodatkowo, na podstawie spisu książek w Lustracji, podał liczbę książek znajdujących się w każdym dziale z rozbiciem na ilość tytułów i tomów. Informacje te z uwagi na brak tego spisu mają charakter unikalny, ale też trudny do sprawdzenia ${ }^{53}$.

\begin{tabular}{|c|c|c|c|c|c|}
\hline \multirow[b]{2}{*}{ Lp. } & \multicolumn{2}{|l|}{ Lustracja } & \multicolumn{3}{|c|}{ Zalewski, Biblioteka seminarium } \\
\hline & Tytuł & Strona & Tytul & $\begin{array}{l}\text { Liczba } \\
\text { dziel }\end{array}$ & $\begin{array}{l}\text { Liczba } \\
\text { tomów }\end{array}$ \\
\hline 1 & 2 & 3 & 4 & 5 & 6 \\
\hline \multirow{3}{*}{1.} & Commentarij in Folio & 54 & \multirow{3}{*}{$\begin{array}{l}\text { Libri commentariorum } \\
\text { in Bibliam }\end{array}$} & \multirow{3}{*}{297} & \multirow{3}{*}{481} \\
\hline & Commentarij in minori Folio & 58 & & & \\
\hline & Commentarij in Quarto & 59 & & & \\
\hline \multirow{3}{*}{2.} & Philosophii in Folio & 60 & \multirow{3}{*}{ Libri philosophici } & \multirow{3}{*}{381} & \multirow{3}{*}{513} \\
\hline & Philosophii in minori Folio & 66 & & & \\
\hline & Philosophii in Quarto & 67 & & & \\
\hline 3. & Mathematici in Quarto & 68 & Libri mathematici & 176 & 197 \\
\hline \multirow{3}{*}{4.} & Theologi in Folio & 72 & \multirow{3}{*}{ Theologi } & \multirow{3}{*}{256} & \multirow{3}{*}{428} \\
\hline & Theologi in minori Folio & 77 & & & \\
\hline & Theologi in Quarto & 78 & & & \\
\hline \multirow{4}{*}{5.} & Historici in Folio Majori & 79 & \multirow{4}{*}{ Historici } & \multirow{4}{*}{428} & \multirow{4}{*}{601} \\
\hline & Historici in Quarto & 85 & & & \\
\hline & Historici in Octauo & 87 & & & \\
\hline & Historici in Duodecimo & 88 & & & \\
\hline 6. & Contionatores & 99 & Concionatorum & 366 & 479 \\
\hline 7. & Ascetae & 102 & Ascetae & 337 & 414 \\
\hline 8. & Opera Patrum & 106 & Opera Patrum & 76 & 112 \\
\hline 9. & Meditatores & 108 & Meditatores & 75 & 284 \\
\hline 10. & Politici & 110 & Politici & 149 & 196 \\
\hline 11. & Rhetores & 114 & Rhetores & 283 & 447 \\
\hline 12. & Elenchus Poetarum & 121 & Elenchus Poetarum & 332 & 449 \\
\hline 13. & Grammatici & 129 & Grammatici & 73 & 98 \\
\hline \multirow[b]{2}{*}{14.} & Medici & 131 & \multirow[b]{2}{*}{ Medici } & \multirow[b]{2}{*}{410} & \multirow[b]{2}{*}{497} \\
\hline & $\begin{array}{l}\text { Medici sub tempus Revisionis } \\
\text { ex Apotheca ad Bibliothecam } \\
\text { translatt. }\end{array}$ & 135 & & & \\
\hline 15. & Libri Italici & 140 & Libri Italici & 222 & 289 \\
\hline 16. & Libri Graeci & 145 & Libri graeci & 64 & 89 \\
\hline
\end{tabular}

${ }^{52}$ L. Zalewski wymienia wszystkich 36 działów - zob. Zalewski, Biblioteka seminarium, s. 243244.

${ }^{53}$ Podane w tabeli przy Lustracji numery stron orientacyjnie mogą wskazywać na przestrzeń potrzebną w rękopisie do spisania książek w danym dziale, a tym samym na obszerność poszczególnych działów. 


\begin{tabular}{|c|c|c|c|c|c|}
\hline 1 & 2 & 3 & 4 & 5 & 6 \\
\hline 17. & Libri Gallici & 147 & Libri Gallici & 120 & 132 \\
\hline 18. & Libri Juris Canonici et Civilis & 149 & Libri iuris canonici & 150 & 183 \\
\hline 19. & Libri Societatis Iesu & 153 & Libri J. C. & 59 & 264 \\
\hline 20. & $\begin{array}{l}\text { Libri Catholici contra } \\
\text { Haeretices }\end{array}$ & 154 & $\begin{array}{l}\text { Libri catholicorum } \\
\text { contra haereticos }\end{array}$ & 441 & 520 \\
\hline 21. & Libri varij ad devotionem & 164 & $\begin{array}{l}\text { Libri varii ad } \\
\text { devotionem }\end{array}$ & 54 & 83 \\
\hline 22. & Kazania Pogrzebowe & 165 & Kazania pogrzebowe & 7 & 7 \\
\hline 23. & Kazania na dni uroczyste & 165 & $\begin{array}{l}\text { Kazania na dni } \\
\text { uroczyste }\end{array}$ & 11 & 36 \\
\hline 24. & Xięgi różne & 165 & Księgi różne & 20 & 100 \\
\hline \multirow{4}{*}{25.} & \multirow{4}{*}{$\begin{array}{l}\text { Mowy przy powitaniu, } \\
\text { pożegnaniu, Reassumpcyi, } \\
\text { Limitie Trybunału }\end{array}$} & \multirow{4}{*}{166} & $\begin{array}{l}\text { Mowy przy } \\
\text { pożegnaniu Trybunału }\end{array}$ & 8 & 19 \\
\hline & & & $\begin{array}{l}\text { Mowy przy reasumpcji } \\
\text { Trybun[ału] }\end{array}$ & 2 & 13 \\
\hline & & & Mowy przy limicie & 7 & 76 \\
\hline & & & $\begin{array}{lr}\text { Mowy } & \text { przy } \\
\text { pożegnaniu Trybunału }\end{array}$ & 8 & 19 \\
\hline \multirow{2}{*}{26.} & \multirow{2}{*}{ Mowy pogrzebowe Nadgrobki } & \multirow{2}{*}{166} & Mowy pogrzebowe & 4 & 17 \\
\hline & & & Nagrobki & 2 & 3 \\
\hline \multirow{4}{*}{27.} & \multirow{4}{*}{-} & & $\begin{array}{l}\text { Libri ad cubiculum R. } \\
\text { P. rhetorices }\end{array}$ & 9 & 9 \\
\hline & & & $\begin{array}{l}\text { Libri ad cubiculum R. } \\
\text { M. syntaxeos }\end{array}$ & 19 & 27 \\
\hline & & & $\begin{array}{l}\text { Libri ad cubiculum R. } \\
\text { M. grammatices }\end{array}$ & 6 & 6 \\
\hline & & & $\begin{array}{l}\text { Libri ad cubiculum R. } \\
\text { M. Infimae }\end{array}$ & 24 & 31 \\
\hline 28. & Libri Germanici & 168 & $\begin{array}{l}\text { Librorum } \\
\text { germanicorum }\end{array}$ & - & 124 \\
\hline 29. & Libri Prohibiti & 168 & Librorum prohibitorum & - & 168 \\
\hline
\end{tabular}

Książki w bibliotece jezuitów w Lublinie były z reguły gromadzone w jednym egzemplarzu, ale przechowywano też dublety. Nie ma pewności czy w Lustracji wliczono je w liczbę tomów, czy też przez termin „tom” rozumiano faktycznie wolumin, a nie egzemplarz. Wiele z podwójnych egzemplarzy już wcześniej mogło zostać przekazanych w inne ręce. W latach 1745-1747 Józef A. Załuski starał się o pozyskanie do własnej biblioteki książek od lubelskich jezuitów, zarówno dubletów, jak i z pojedynczych egzemplarzy. Za zgodą prowincjała zakonu książki z biblioteki lubelskiej zostały przekazane do Warszawy w połowie stycznia 1747 r. ${ }^{54}$ Być może były kolejne transporty.

${ }^{54}$ Grzebień, Józef Andrzej Zatuski, s. 64-65; Niesiecki, List Kaspra Niesieckiego SJ do Józefa Andrzeja Zatuskiego, s. 134. 


\subsection{Zawartość}

Zachowane informacje pozwalają na dokonanie ogólnej charakterystyki księgozbioru w bibliotece lubelskiego kolegium. Można powiedzieć, że składał się z książek, których tematyka była powszechnie spotykana w bibliotekach jezuickich $^{55}$. Największą grupę tworzyły książki o tematyce religijnej. Znajdowały się więc w niej komentarze do Pisma Świętego, ale nie wykluczone, że wśród nich były też wydania Biblii, których spis w Lustracji osobno nie wymienia. Do grupy tej wchodzą druki z zakresu teologii, kaznodziejstwa i pisma ojców Kościoła. Wśród 256 dzieł teologicznych w 428 tomach, reprezentowane były zapewne różne działy teologii, chociaż w spisie zostały potraktowane łącznie pod jednym tytułem, o ile nie liczyć zróżnicowania pod względem formatu. Osobną grupę stanowią autorzy określeni mianem „Meditatores”, pod którym kryje się dział literatury myślicielskiej, reprezentowanej tu przez 75 pozycji w 284 tomach. Do książek religijnych należą też spisane osobno dzieła i traktaty polemiczne $\mathrm{z}$ różnowiercami (Libri catholicorum contra haereticos), książki o tematyce dewocyjnej (Libri varii ad devotionem), ale też zbiory kazań pogrzebowych i na uroczyste okazje. Zwraca uwagę duża liczba książek polemicznych (441 tytułów w 520 tomach), największa spośród różnych rodzajów druków o tematyce religijnej, co odpowiada roli, jaką zakon jezuitów pełnił w działalności kontrreformacyjnej.

Ważne miejsce zajmował dział filozofii z 381 tytułami w 513 tomach. Sąsiadował on z odrębnym dość licznym działem „Libri mathematici”, w którym mogły się też znajdować książki z zakresu logiki, osobno nie wydzielone, o ile nie umieszczono ich w ramach działu filozoficznego.

W księgozbiorach jezuickich tradycyjnie bogato były reprezentowane prace o tematyce historycznej. Podobnie było w bibliotece lubelskiej, w której zgromadzono 428 tytułów w 601 tomach. Domyślać się można, że dotyczyły one historii biblijnej, starożytnej, ale też, a może przede wszystkim, dziejów państw i ludów europejskich. Znacznie skromniejszy był dział książek nazwanych „Politici”, liczył 149 tytułów i 196 tomów. Niewykluczone, że w tej grupie, oprócz autorów piszących o polityce, mieściły się też książki o tematyce ekonomicznej, zastanawia bowiem ich brak w systematyce biblioteki jezuitów lubelskich. Bogato za to są reprezentowane książki prawnicze, których łącznie było 209, z zakresu prawa kanonicznego 150 tytułów w 183 tomach i prawa świeckiego (Libri J. C.) 59 tytułów w 264 tomach.

W każdej bibliotece kolegium jezuickiego ważne miejsce zajmowały książki związane z przedmiotami określanymi mianem „humaniora”, czyli tymi, które

${ }^{55}$ Dla przykładu por. zawartość bibliotek jezuitów krakowskich - L. Grzebień, Biblioteki jezuickie w Krakowie od XVI do XVIII wieku, w: Librorum amatori. Księga pamiatkowa ofiarowana ks. Czesławowi Michalunio SJ na 50-lecie ofiarnej pracy w Bibliotece Filozoficznej Towarzystwa Jezusowego w Krakowie, red. A.P. Bieś SJ, Kraków 2004, s. 33-34, 45, 49-50. O zawartości bibliotek jezuickich w Polsce informują prace dotyczące dziejów tych bibliotek - zob. A.P. Bieś, Podstawowa bibliografia jezuickich bibliotek w Polsce, w: Librorum amatori. Księga pamiatkowa ofiarowana ks. Czestawowi Michalunio SJ na 50-lecie ofiarnej pracy w Bibliotece Filozoficznej Towarzystwa Jezusowego w Krakowie, red. A.P. Bieś SJ, Kraków 2004, s. 193-200. 
miały kształtować formację intelektualną uczniów, opartą na znajomości łaciny i greki, dzieł antycznych i retoryki. Z podobną sytuacją spotykamy się w kolegium lubelskim, w bibliotece którego znajdowały się trzy bogate działy, gromadzące książki z zakresu retoryki ( 283 dzieł i 447 tomów), gramatyki (73 tytułów i 98 tomów) i zbiory poetów (332 tytułów w 449 tomach).

W bibliotece jezuitów lubelskich zwraca uwagę duży udział książek z zakresu medycyny. L. Zalewski podawał liczbę 410 tytułów w 497 tomach. Faktycznie w bibliotece wspólnej było tylko około połowy tej liczby, drugie tyle książek pochodziło z biblioteki apteki klasztornej, z której księgozbiór został przeniesiony do biblioteki domowej w czasie inwentaryzacji majątku pojezuickiego ${ }^{56}$. Niestety podobnie, jak w przypadku pozostałych działów nic nie wiadomo o tytułach poszczególnych książek.

W bibliotece jezuitów lubelskich nie zabrakło także książek o charakterze praktycznym, które były wykorzystywane przy szczególnych okazjach. Takie przeznaczenie miały już wspomniane wcześniej zbiory kazań pogrzebowych i na dni uroczyste, ale tego rodzaju książek w bibliotece było więcej. Stanowiły je głównie zbiory mów wygłaszanych w czasie sesji Trybunału Koronnego w Lublinie. Były to więc mowy przy powitaniu, reasumpcji, odroczeniu i pożegnaniu Trybunału oraz mowy pogrzebowe. Osobną grupę tworzyły książki opatrzone nazwą „Nagrobki”, pod którą można domyślać się zbiorów inskrypcji nagrobnych. Nie były to liczne działy książek, z reguły znajdowało się w nich po kilka książek, nie przekraczały 10 tytułów.

W Lustracji zostały wyróżnione $\mathrm{w}$ osobnych grupach książki w językach: włoskim (Libri italici), greckim (Libri graeci), francuskim (Libri gallici) i niemieckim (Libri germanici). Były to książki uznawane za obcojęzyczne, tzn. pisane w innym języku niż łacina lub język polski. Nie wiadomo, czy poszczególne grupy językowe stanowiły osobne działy w bibliotece, czy też podział ten jest rezultatem prac inwentaryzacyjnych lustratorów, którzy sami dokonali podziału książek z uwagi na język. Tak czy inaczej, książki o tym samym języku zestawiono razem, co umożliwiło ks. L. Zalewskiemu podanie ich liczby. Najliczniej były reprezentowane książki w języku włoskim (222 tytułów i 289 tomów), książek w języku francuskim było odpowiednio 120 i 132, a wydrukowanych w języku greckim 64 i 89. Dla książek niemieckich znamy tylko liczbę tomów - 124, tytułów mogło być zatem około stu. Nic nie wiadomo o treści książek obcojęzycznych, można się domyślać, że tematycznie odpowiadały działom reprezentowanym w bibliotece wspólnej.

${ }^{56}$ Wielkość zbioru książek medycznych w bibliotece wspólnej i pochodzących z biblioteki apteki, można orientacyjnie obliczyć na podstawie liczby książek podanej przez ks. L. Zalewskiego i liczby stron, na których w Lustracji zostały wymienione te książki. Ks. Zalewski podawał 410 tytułów książek medycznych. Na podstawie Lustracji wiadomo, że „Medici” zostały opisane na s. 131-134/135, a książki przeniesione z apteki na s. 135-139/140. Na opisanie książek medycznych dla każdej z obu grup potrzeba było ok. 5 stron w oryginale Lustracji, co stanowiło połowę przestrzeni przeznaczonego dla całego działu medycznego. Można przyjąć, w tej części mieściła się połowa liczby książek medycznych, czyli ok. 200. 
W bibliotece lubelskich jezuitów istniał osobny dział nazwany w Lustracji „Libri prohibiti”. Dział książek zakazanych byłby dla nas szczególnie interesujący, gdyż na ogół rzadko je przechowano. W Lustracji niestety tytuły dzieł nie zostały wymienione, podano jedynie ogólną ich ilość.

\section{Biblioteki i księgozbiory specjalne}

Ważne miejsce w systemie bibliotek domu zakonnego zajmowały biblioteki i księgozbiory specjalne. Gromadzono je osobno, bez związku z księgozbiorem biblioteki wspólnej, zalecano nawet, aby książki biblioteki domowej i bibliotek specjalnych nie mieszały się ze sobą. Biblioteki i księgozbiory specjalne powstawały w związku z organizacją placówki, urzędami i funkcjami oraz obszarami działania, miały charakter podręczny i służyły do bezpośredniego wykonywania obowiązków i czynności. Ich obecność w domach zakonnych była na tyle istotna, że ostatni w okresie przedkasacyjnym generał Ricci, w specjalnej instrukcji z 1763 r. uregulował zasady ich działania ${ }^{57}$. Nie wiadomo na ile te przepisy zmienily charakter bibliotek specjalnych w kolegium lubelskim, w ostatnim dziesięcioleciu jego istnienia, można raczej sądzić, że na obraz tych bibliotek, jaki tworzymy głównie na podstawie lektury Lustracji, składa się także ich wcześniejszy sposób funkcjonowania.

L. Grzebień w swojej pracy o organizacji bibliotek jezuickich wymienia aż 26 różnych bibliotek i księgozbiorów specjalistycznych, przy czym jest to katalog stworzony w odniesieniu do wszystkich dawnych placówek jezuickich, natomiast w poszczególnych przypadkach ilość i rodzaje bibliotek specjalnych była dostosowana do miejscowych potrzeb. Podobnie było zapewne w kolegium lubelskim, w którym jest poświadczone istnienie co najmniej dwunastu bibliotek i księgozbiorów specjalnych. Stosunkowo więcej wiadomo na temat dwóch bibliotek działających w ramach jezuickich struktur szkolnych, mianowicie biblioteki seminarium kleryków i biblioteki konwiktu, o pozostałych informacje pochodzą z Lustracji. Można się spodziewać, że dokładne rozpoznanie znaków i not proweniencyjnych na zachowanych egzemplarzach książek, uzupełni naszą wiedzę o tego rodzaju bibliotekach w kolegium lubelskim.

Biblioteka seminarium była związana z działalnością seminarium, które zostało utworzone w 1675 r. przy kolegiacie św. Michała w Lublinie. Podlegało ono opiece rektora miejscowego kolegium jezuickiego, a jezuici mieli kierować kształceniem kleryków. Dla potrzeb kształcenia kleryków zaczęto tworzyć odrębny księgozbiór, który w 1692 r. był już dość znaczny i składał się z ponad 100 książek $^{58}$. Biblioteka kleryków była odrębna od biblioteki kolegium, w notach proweniencyjnych podkreślano tę niezależność przez używanie własnej nazwy „Ex libris Clericorum Seminarii Lublinensis”. Prowadzono też dla niej odrębny katalog ${ }^{59}$. Biblioteka rozwijała się głównie dzięki darom, nie osiągnęła jednak szczególnie znacznych rozmiarów, w chwili zamknięcia liczyła 359 tomów.

\footnotetext{
${ }^{57}$ Grzebień, Organizacja bibliotek, s. 42-43.

${ }^{58}$ Zalewski, Biblioteka seminarium, s. 25.

${ }^{59}$ Tamże, s. 25-27.
} 
W 1760 r. jezuici przestali pełnić opiekę nad seminarium, a księgozbiór biblioteki w całości został spisany i przekazany księżom misjonarzom ${ }^{60}$.

Poza seminarium kleryków, lubelscy jezuici prowadzili drugą instytucję szkolną, której celem było rozwijanie funkcji edukacyjnej kolegium. W latach 40. XVIII w. jezuici czerpiąc wzory z Collegium Nobilium Stanisława Konarskiego, zaczęli tworzyć szkoły nowego typu przeznaczone dla młodzieży szlacheckiej. W 1752 r. jezuici uzyskali przywilej królewski na założenie takiej placówki w Lublinie, która przez pierwsze dwa lata działała jako konwikt, ale z braku uczniów nie rozwinęła się w pełnoprawne kolegium szlacheckie ${ }^{61}$. Na potrzeby edukacyjne starano się zakładać osobne biblioteki, chociaż powstając zaledwie kilkanaście lat przez rozwiązaniem zakonu, nie miały one szans rozwinąć się w większe księgozbiory. Biblioteka konwiktu w Lublinie była raczej skromna, składała się z 30 dzieł w 32 woluminach. Przechowywano ją w szafce w pierwszej izbie konwiktu. Księgozbiór składał się z ośmiu książek o tematyce religijnej, pięciu słowników i dykcjonarzy, czterech dzieł z historii polskiej i powszechnej, po jednej pozycji o tematyce przyrodniczej i prawniczej. Resztę księgozbioru uzupełniały edycje literatury starożytnej, służące do nauki poetyki i retoryki ${ }^{62}$. Pomimo skromnego ilościowo zestawu książek, wydaje się, że wystarczał on na potrzeby nielicznej grupy uczniów, którzy i tak na lekcje chodzili do kolegium. Losy biblioteki konwiktorskiej były związane z historią pozostałości po skasowanym kolegium.

Odrębny rodzaj bibliotek specjalnych stanowiły księgozbiory profesorów wykładających $\mathrm{w}$ kolegium na różnych poziomach nauki. Zgodnie z instrukcją ks. Ricciego, pokoje powinny być wyposażone w porządne szafy z książkami ${ }^{63}$. Istotnie, w Lustracji $\mathrm{w}$ opisie niektórych pokoi profesorskich, podano informację o szafach na książki, a nawet ich usytuowaniu. W kolegium jezuickim w Lublinie poświadczone jest istnienie bibliotek profesorów teologii, retoryki, syntaksy, gramatyki i infimy. Stancja dla pierwszego profesora teologii była wyposażona W szafki na książki, ale o samym księgozbiorze wiadomo niewiele. W czasie inwentaryzacji, w pomieszczeniu znajdowały się tylko Prelectiones theologiae ${ }^{64}$ i zapewne rękopiśmienny rejestr zmarłych jezuitów w Lublinie. Pokój dla drugiego profesora teologii miał szafę w murze na książki z trzema półkami, ale żadnych książek nie znaleziono ${ }^{65}$. Profesor retoryki posiadał księgozbiór złożony z dziewięciu dzieł w tyluż tomach. Być może jednym z nich był zachowany do dziś in-

${ }^{60}$ Tamże, s. 28-29; Piechnik, Seminaria diecezjalne, s. 250-252. Jak już wspomniano wcześniej, biblioteka kleryków seminarium zasługuje na oddzielne opracowanie, stąd nie jest szerzej tu omawiana. Warto dodać, że obok katalogów biblioteki sporządzonych w czasie jej przekazywania przez jezuitów księżom misjonarzom, wymienionych przez ks. L. Zalewskiego, zachował się jeszcze jeden spis przechowywany dziś w Bibliotece Narodowej w Warszawie, sygn. III 6878.

${ }^{61}$ L. Zalewski, Orlęta lubelskie. Nauka, wychowanie i życie młodzieży męskiej w Lublinie 15861773, Lublin 1947, s. 35-42.

${ }^{62}$ Tamże, s. 39-40.

${ }^{63}$ Grzebień, Organizacja bibliotek, s. 42.

${ }^{64}$ Pod tym tytułem może występować dzieło P.M. Gazzanigna, Praelectiones theologicae, 4 vol., Vindobonae 1763-1766.

${ }^{65}$ Lustracja, s. 1188. 
kunabuł z notą „Inscriptus cathalogo lib(rorum) Collegii Societatis Jesu Lublini n 4 pro Professore Humanitatis" ${ }^{66}$. Wskazuje ona, że książka należała do profesora tzw. humaniora, czyli klasy, która obejmowała dwie ostatnie klasy nauki - poezji i retoryki. Znacznie więcej w swojej bibliotece miał profesor syntaksy, czyli klasy, w której przerabiano składnię i doskonalono znajomość gramatyki. Zgromadził 19 tytułów w 27 tomach. Z kolei profesor gramatyki miał tylko sześć dzieł w takiej samej liczbie tomów. Dość liczną bibliotekę zgromadził profesor infimy, czyli najniższej klasy, w której rozpoczynano naukę od początków łaciny i greki. Księgozbiór ten składał się z 24 książek w 31 tomach $^{67}$. Niestety, poza danymi ilościowymi nic nie wiadomo o zawartości bibliotek profesorów lubelskich. Można próbować ją ustalić na podstawie szerszej wiedzy z dziejów oświaty jezuickiej.

W lubelskim kolegium książki znajdowały się także w pomieszczeniach o wspólnym przeznaczeniu, nie związanych z pełnionymi urzędami, czy funkcjami. Do nich należały tzw. kommune, czyli obszerne izby przeznaczone dla scholastyków i teologów do zamieszkania na zimę ${ }^{68}$. W pomieszczeniu opisanym jako „komora wielka czyli kommune” znajdowały się cztery książki włoskie, nie podano ich tytułów. W drugiej kommune przeznaczonej dla profesorów szkół znajdował się druk z regułami zakonu franciszkanów in quarto zatytułowany Statuta minorum Fratrum s. Francisci ${ }^{69}$. Trudno powiedzieć, czy książki te stanowiły części większych księgozbiorów gromadzonych w tych miejscach.

Z bibliotek specjalnych osób sprawujących urzędy, znany jest księgozbiór ostatniego prokuratora ekonomicznego kolegium z czasów kasaty zakonu. Prokurator zajmował się sprawami finansowymi, administracyjnymi i gospodarczymi, nie uczył w szkołach, kazań przeważnie nie głosił, stąd w swoim pokoju posiadał nieduży podręczny księgozbiór. Składał się z siedmiu książek, wśród których jedna pozycja $\mathrm{w}$ wielu egzemplarzach była wyraźnie przeznaczona na sprzedaż. Księgozbiór składał się z kilku pozycji głównie o tematyce historycznej i filozoficznej. Tworzyły go: dzieło Gestonem in Europa w języku francuskim w formacie in folio; rękopiśmienny traktat filozoficzny o nieznanym tytule in quarto; benedykcjonał, nazwany tu jako „książeczka do Benedykcji”; książka Iter felix, edycja Metamorfozy Owidiusza prawdopodobnie w wydaniu z $1701 \mathrm{r}^{70}$, kalendarzyki warszawskie w ilości 70 egzemplarzy (,,in crudo”) oraz książka opisana jako „historie azjatyckie patrum Soc. Jezu in quarto" 71 . W księgozbiorze prokuratora znajdowało się pięć rejestrów rękopiśmiennych oprawnych i jeden z wydartymi

${ }^{66}$ M.T. Cicero, Tusculanae disputations[...], Venezia 1499, egzemplarz z WBPHŁ w Lublinie, sygn. 15-f-16.

${ }^{67}$ Zalewski, Biblioteka seminarium, s. 244.

${ }^{68}$ Zalewski, Katedra, s. 71.

${ }^{69}$ Lustracja, s. 1189. Prawdopodobnie chodzi o druk wydany w drukarni lubelskiej jezuitów Statuta Fratrum Minorum Regularis Observantiae S. P. N. Francisci [...]. Impressa Anno Domini 1769. Lublini, Typis S. R. M. Collegi Societatis Jesu.

${ }^{70} \mathrm{~W}$ odpisie Lustracji (s. 1169) książka ta jest opisana jako Ondy [sic!] Nasonis Justum, może tu zatem chodzić o edycję Publii Ovidii Nasonis Metamorphoseon libri XV. Francofurti, Lipsiae, apud J. Justum Erythropilum, 1701.

${ }^{71}$ Lustracja, s. 1178-1179. 
kartami oraz inwentarz dóbr kolegium lubelskiego i inwentarz drukarni, a ponadto wiele ,innych rejestrów pisanych i książeczek na nie zdałych" "72.

Wśród różnych rodzajów bibliotek specjalistycznych L. Grzebień wymienił także bibliotekę drukarni. W jej skład wchodziły książki przeznaczone do rozprowadzenia, w tym do sprzedaży, rękopisy do druku i książki przekazane przez inne drukarnie $^{73}$. Taki rodzaj biblioteki funkcjonował także w kolegium w Lublinie, chociaż nie jest znana jej cała zawartość. W samej drukarni w czasie inwentaryzacji nie znaleziono żadnych książek, były one przechowywane w dwóch innych pomieszczeniach. W kolegium znajdowały się dwie izby na skład książek, jedna - „komora, gdzie książki do sprzedania składają się" „złożenie ksiąg in credo”, w której znajdowało się dziewięć szaf na książki wokół pod ścianami i dwie szafy na środku oraz stół z szafami podwójnymi ${ }^{75}$. Liczba książek znajdujących się na stanie tych pomieszczeń była znaczna, na podstawie Lustracji wiadomo, że tytułów książek do sprzedaży było 109 w 1.069 tomach, a do oprawy 90 dzieł w 29.804 egzemplarzach $^{76}$.

Osobny księgozbiór posiadała także klasztorna apteka. Informacja o niej pochodzi z Lustracji, gdzie w spisie działów rzeczowych biblioteki zapisano, że w czasie inwentaryzacji książki medyczne zostały z apteki przeniesione do biblioteki wspólnej ${ }^{77}$. Poza ogólną informacją, że książki te dotyczyły tematyki medycznej, nic więcej nie wiadomo o zawartości księgozbioru apteki. Można jedynie orientacyjnie szacować jego wielkość, który był dość pokaźny i prawdopodobnie liczył około 200 tytułów $^{78}$.

Do księgozbiorów specjalnych należały też książki będące na wyposażeniu kościoła klasztornego. Wiadomo, że w świątyni lubelskiej znajdowały się: jeden pontyfikał w czerwoną skórę oprawiony ${ }^{79}$, jeden psałterz stary w oprawie skórzanej, 12 egzemplarzy mszałów oprawionych w skórę, 16 egzemplarzy mszałów żałobnych, jedna agenda wielka, dwie agendy małe i jeden brewiarz chórowy ${ }^{80}$.

Działające przy kościele jezuickim w Lublinie bractwa także posiadały swoje księgozbiory. W kongregacji palestrańskiej znajdowały się następujące księgi: zapewne rękopiśmienny egzemplarz księgi brackiej, zatytułowanej Album sodalium, oprawionej w czerwoną skórę, jedna książka o historii kongregacji, jedna pozycja pod nazwą Regestra kongregacji i 24 egzemplarze księgi liturgicznej $O f$ ficium de Beata ${ }^{81}$. W kongregacji studium większego znajdowały się 22 egzem-

\footnotetext{
72 Tamże, s. 1179.

${ }^{73}$ Grzebień, Organizacja bibliotek, s. 72-73.

${ }^{74}$ Lustracja, s. 1168.

${ }^{75}$ Tamże, s. 1189-1190.

${ }^{76}$ Zalewski, Biblioteka seminarium, s. 244.

${ }^{77}$ „Medici sub tempus Revisionis ex Apotheca ad Bibliothecam translatt.”-Lustracja, s. 1519.

${ }^{78}$ Zob. wyżej przyp. 56.

${ }^{79}$ Pontyfikał być może tożsamy z Pontificale Romanum z napisem „Inscriptus catalogo librorum Societatis Jesu Lublinensis, applicat templi 1700”, przechowywanym dziś w Bibliotece „Bobolanum" w Warszawie - zob. Grzebien, Organizacja bibliotek, s. 71.

${ }^{80}$ Lustracja, s. 1236.

${ }^{81}$ Tamże, s, 1240.
} 
plarze książek do nabożeństwa, mszał i brewiarz, z kolei w kongregacji studium mniejszego znajdowało się 61 różnych książek ${ }^{82}$.

\section{Przechowywanie i zabezpieczanie zbiorów}

Jezuici lubelscy przykładali duże znaczenie do przechowywania i uporządkowania zbiorów bibliotecznych. Odnowienie i wzorowe urządzenie pomieszczenia biblioteki w latach 50. XVIII w. jest najlepszym świadectwem ich starań o stworzenie właściwych warunków gromadzenia, przechowywania i użytkowania zbiorów. Starania te widać także w zakresie zabezpieczenia samych książek w solidne i estetycznie wykonane oprawy. Wiele starszych książek zostało oprawionych w deski powleczone skórą. Na wierzchnich i tylnych okładkach zostały wyciśnięte radełkiem lub plakietami ozdoby, połączone często z inskrypcją proweniencyjną o pochodzeniu z kolegium lubelskiego: COLL. LVBLIN. SOC. IESV. ${ }^{83}$ Niewykluczone, że książki te były oprawiane we własnym warsztacie introligatorskim, lub ściśle współpracującym z jezuitami. W inwentarzu drukarni z okresu kasaty znajdują się wymienione narzędzia introligatorskie, co może wskazywać, że jezuici we własnym zakresie oprawiali książki ${ }^{84}$. Mogli zajmować się oprawą książek co najmniej od początku działania drukarni, czyli od lat 80. XVII stulecia.

Jak już wcześniej wspomniano jezuici mieli obowiązek prowadzenia katalogów bibliotecznych, zarówno dla księgozbioru wspólnego, jak i księgozbiorów specjalistycznych $^{85}$. Katalogi biblioteki kolegium jezuickiego sprzed kasaty nie zachowały się, ale zapewne były prowadzone. Na wielu egzemplarzach książek należących do lubelskich jezuitów znajdujemy notę proweniencyjną w brzmieniu: „Inscriptus Catalogo Libror(um) Coll(egii) Lubl(inensis) Soc(ietatis) Jesu”, która poświadcza istnienie takiego katalogu. O istnieniu katalogu biblioteki, pomimo wymieniania w Lustracji różnych regestrów pozostawionych przez lubelskich jezuitów, nie wspomina się, co może oznaczać, że już go wówczas nie było. Katalogi są świadectwem porządku, który próbowano wprowadzić w świat książek i czytelników. Katalog wskazywał lokalizację książek w bibliotece, opisywał ich przynależność do poszczególnych działów przedmiotowych oraz miejsce w szafie i na półce. Najstarsze książki z biblioteki kolegium lubelskiego posiadają noty proweniencyjne, w których podawano numer katalogowy ${ }^{86}$. W katalogu pod kolejnymi numerami były opisane konkretne książki, według autora i tytułu, ale może też i innych danych identyfikacyjnych, takich jak miejsce i rok wydania,

${ }^{82}$ Tamże, s. 1241 i 1243.

${ }^{83}$ Zob. przykład takiej oprawy na egzemplarzu z dzisiejszej Biblioteki „Bobolanum” - Grzebień, Organizacja bibliotek, s. 126.

${ }^{84}$ Wśród narządzi introligatorskich zostały wymienione: prasa introligatorska, lada (?) do zszywania, stemple do „wyzłacania książek”, radełko (,kółko do fugowania”) - Lustracja, s. 1246.

${ }^{85}$ Zob. przyp. 5.

${ }^{86}$ Przykłady znanych not z zachowanych druków w Bibliotece „Bobolanum” podaje L. Grzebien, Organizacja bibliotek, s. 156-157: ,inscriptus catalogo librorum collegi Lublinensis Societatis Jesu sub num. 6" i ,inscriptus catalogo librorum collegi Lublinensis Societatis Jesu sub num. 10”. Por. L. Grzebień, Katalog starych druków biblioteki teologicznej Bobolanum, „Archiwa, Biblioteki i Muzea Kościelne”, 16 (1968) numery: 7, 36, 41, 59. 
ewentualnie nazwiska drukarza. Obok musiały znajdować się oznaczenia literowe i numeryczne, które prowadziły do konkretnej szafy lub półki. Dzięki nim można było łatwo trafić do żądanej pozycji ${ }^{87}$. Katalogi mogły niekiedy także informować o czasie dokonywania nabytków, co przybliża je bardziej do roli inwentarza bibliotecznego. Znana jest zapiska proweniencyjna na książce razem z datą wpisania do katalogu: ,inscriptus catalogo librorum collegi Lublinensis Societatis Jesu 15 Augusti 1700"

Książki w bibliotece lubelskich jezuitów miały zróżnicowane formaty. Występowało sześć formatów: in folio majori, in folio, in minori folio, in quarto, in octavo, in duodecimo, a najbardziej zróżnicowane rozmiary posiadały książki o tematyce historycznej (in folio majori, in quarto, in octavo, in duodecimo) ${ }^{89}$. Przynajmniej część książek w szafach biblioteki wspólnej była ustawiona formatami. Może na to wskazywać sposób ich spisania w Lustracji, gdzie książki o tej samej tematyce były w osobnych grupach, wydzielonych w zależności od formatu. Taki porządek przyjęto dla czterech pierwszych działów: komentarzy, filozofii, teologii i historii.

\section{Losy księgozbioru}

Losy biblioteki jezuickiej wyraźnie wpisują się w ogólniejsze dzieje przemian kulturalnych i oświatowych końca XVIII i początku XIX wieku. Po kasacie zakonu jezuitów, ich biblioteki, według przepisów Komisji Edukacyjnej, zasiliły zbiory uniwersyteckie Krakowa, Lwowa i Wilna oraz księgozbiory szkolne. Jakaś część bibliotek złożona została w innych klasztorach, wiele książek z jezuickich bibliotek zostało sprzedanych w drodze licytacji osobom prywatnym zarówno miłośnikom ksiąg, jak i za cenę papieru. Niektóre dzieła trafiły do rąk duchownych $\mathrm{z}$ parafii położonych w sąsiedztwie klasztorów ${ }^{90}$. Różne też były losy księgozbiorów, które trafiły do bibliotek szkolnych. W praktyce pod znakiem zapytania była przydatność do użytku szkolnego dawnych dzieł teologicznych, religijnych, filozoficznych i podręczników. Komisja i Towarzystwo do Ksiąg Elementarnych starannie opracowały treści nauczania oparte na klasyfikacji nauk Francisa Bacona i modernizacji Jeana d'Alamberta, w ogólnym zamierzeniu mające odejść od łacińskiej tradycji i jezuickiego sposobu nauczania ${ }^{91}$. Stworzono nowy program nauczania w szkołach wojewódzkich, jak i też przystąpiono do pisania nowych podręczników. Chociaż prace nie postępowały tak szybko jak pierwotnie zakładano, to ostatecznie ukazało się tylko 29 podręczników, pomimo prac nad 50 tego typu książek. W redakcji pozostało 15 podręczników, podobnie jak 6 ksiąg pomocniczych. Jednak, mimo zaleceń, w użyciu pozostawały dawne podręczniki,

${ }^{87}$ Nie wydaje się, aby podany w nocie proweniencyjnej numer odnoszący do katalogu był jednocześnie oznaczeniem szafy lub półki, jak twierdził L. Grzebień, Katalog starych druków Biblioteki ,Bobolanum”, s. 243-245.

${ }^{88}$ Tamże, s. 152.

${ }^{89}$ Lustracja, s. 1518.

${ }^{90}$ Zniesienie zakonu Jezuitów w Polsce i jego zachowanie na Białej Rusi, „Przegląd Lwowski”, 8 (1874) s. 117-118. A. Kempa, Losy jezuickich księgozbiorów, „Bibliotekarz”, 9 (2009) s. 29.

${ }^{91}$ Cz. Majorek, Ksiązki szkolne Komisji Edukacji Narodowej, Warszawa 1995, s. 27. 
czego dowodem był wznawiany kilkunastokrotnie po 1773 r. podręcznik Alwara De institutione grammatica libri III. Ustawicznie modernizowany, chociaż trwale oparty na pamięciowym sposobie nauczania i nie do końca odpowiadający aktualnym potrzebom, nadal pozostawał $\mathrm{w}$ obiegu ${ }^{92}$. Podobnie rzecz miała się ze stosowanym w szkołach jezuickich podręcznikiem Jana D. Musatiego Tabulae chronologicae wydanym w Rzymie w $1708 \mathrm{r}$. dotyczącym historii powszechnej, a dokładniej historii biblijnej, historii wschodu i starożytnego Rzymu używanym w szkołach jezuickich, wznawianym kilkakrotnie w drukarni sandomierskiej ${ }^{93}$. Analogiczna sytuacja dotyczyła pracy W. Rzewuskiego Zabawki dziejopisarskie, albo zebranie dziejów znakomitszych od stworzenia świata do początków wieku naszego (1766) wydanej w oficynie lwowskich jezuitów.

Trzeba też wspomnieć, że radykalne zmiany w nauczaniu, jakie niosły reformy KEN, spotkały się z niechęcią znacznej części szlachty, obawiającej się posyłać swoich synów do szkół nowego typu. Odnosząc się jedynie do programów nauczania, zastrzeżenia dotyczyły nadmiernego eksponowania języka ojczystego w nauczaniu i niedostatku łaciny. Jak pisał w imieniu swoim i okolicznego ziemiaństwa Andrzej Koźmian, w liście wystosowanym do Ignacego Potockiego w październiku 1779 r., sprzeciw budziło wysunięcie na pierwszy plan nauczania języka polskiego. Koźmian domagał się wycofania podręcznika Kopczyńskiego, który „głowy zawraca i łacinę w zapomnienie rzuca. W miejsce dobrych alwarów i gramatyk pijarskich wprowadza się nowe podręczniki do nauczania języka, które dziecko zna od kołyski i nie potrzebuje się go uczyć". Podkreślał za to przydatność łaciny dla polskiej młodzieży, bo to przygotowuje do zawodów statysty, prawnika, gospodarza i żołnierza ${ }^{94}$.

Sytuację zbiorów, jako nieaktualnych w nowej rzeczywistości, odzwierciedla w jakimś stopniu stwierdzenie, jakie padło w 1790 r. na obradach Zgromadzeń Akademickich Wydziału Małopolskiego w Lublinie. Jak pisano „między innymi przyczynami przeszkadzającymi wzrostowi nauk jest niedostatek biblioteki [...]. Zamienienie książek w bibliotekach na inne potrzebniejsze dla nauczycielów, mogłoby zaoszczędzić kosztu"95.

Również lubelska biblioteka przeszła na użytek szkoły podwydziałowej, powstałej w miejsce jezuickiej. W dniu 9 września 1780 r. objęli ją w zarząd sprowadzeni profesorowie akademicy. Panuje opinia, że niewiele okazali oni troskliwości o książki, tym bardziej, że przydatność tego wielotysięcznego księgozbioru stanęła pod znakiem zapytania wobec reform KEN. Decydujące jednak znaczenie dla losów biblioteki, miała sytuacja związana ze stanem i przyszłością całego kompleksu zabudowań pojezuickich. Budynki te nie były w dobrym stanie

${ }^{92}$ Tamże, s. 387-388.

${ }^{93}$ Tamże, s. 370.

${ }^{94}$ W. Smoleński, Pisma historyczne, t. 2, Kraków 1901, s. 209-203, za: J. Dobrzański, Lubelska szkoła Komisji Edukacji Narodowej, w: Ze studiów nad Komisją Edukacji Narodowej i szkolnictwem na Lubelszczyźnie. Rozprawy i artykuły, red. J. Dobrzański, A. Koprukowniak, Lublin 1973, s. 276.

${ }^{95}$ Z. Kukulski, Obrady zgromadzeń akademickich Wydziału Małopolskiego w Lublinie w 1790 r., Lwów 1923, s. 14. Zob. M. Wełna-Adrianek, Początki bibliotekarstwa publicznego w Lublinie, „Roczniki Biblioteczne”, 14 (1970) z. 3/4, s. 704. 
technicznym, mury i dachy wymagały pilnych remontów, a ich opóźnianie lub zaniechanie powodowało dalszą degradację. Duże nadzieje na poprawę sytuacji wiązano z trynitarzami, którym Komisja Edukacyjna protokolarnie przekazała we wrześniu 1781 r., w trwałe posiadanie całego kompleksu pojezuickiego (kościoła, kolegium i szkół). Pomimo wysiłków trynitarzy i podjęcia prac remontowych, o naprawie całego dawnego kolegium nie mogło być mowy z uwagi na duże koszty takiego przedsięwzięcia.

Niestety, najpilniejsze prace remontowe, które podjęli trynitarze nie objęły pomieszczenia biblioteki. Z pochodzących $\mathrm{z}$ tego czasu informacji, wyłania się smutny obraz dawnej biblioteki jezuickiej. Książki nie posiadały katalogu, znajdowały się w nieładzie, część z nich była zawilgocona i zapleśniała, osiadał na nie kurz, a ze sklepienia sypał się gruz. Pomimo tego stanu, biblioteka dawnego kolegium wciąż zachwycała swoją wielkością i wyglądem. Wspaniałość pomieszczeń bibliotecznych nie uszła uwagi współczesnych. Pamiętnikarz Józef Rulikowski, co prawda po latach, tak wspominał swoje odwiedziny w bibliotece pojezuickiej w 1789 r.:

Po lewej stronie, w kwadracie obszernym, była biblioteka pojezuicka, przechodząca prawie dwa piętra, szafy piękne ozdobne malowidłem i pozłotą na snycerskiej robocie, a nad nimi galeria z piękną balustradą, pod ścianami półki. Znajdowało się tam jeszcze książek ze dwanaście do piętnastu tysięcy, opylonych, uszkodzonych, w największym nieporządku. Profesorowi Zalewskiemu poleciła Komisja Edukacyjna, żeby przyprowadził do porządku bibliotekę i katalog ułożył: pracowało nad tym jego dwóch pomocników i co już raz było uporządkowane, tego dotykać się nie było można, lecz co jeszcze zostawało w nieładzie rozbierano za rewersami bez powrotu i jak pamiętam ks. Kowalski, mój profesor, wiele dzieł pięknych i kosztownych wybrał z biblioteki z obietnicą, że zwróci, a jednak w czasie swej choroby wszystkie książki zmarnotrawili6.

Dopiero w 1789 r. Komisja Edukacyjna zarządziła spisanie biblioteki. Pracę tę powierzono prefektowi ks. Wędykowskiemu i profesorowi ks. Zaleskiemu. W pracy wspomagali ich dwaj pomocnicy. Książek uporządkowanych i spisanych nie można było już ruszać, jednocześnie nie zabezpieczono pozostałych woluminów. Pozostawały one nadal w nieładzie i można je było wypożyczać na rewers. Często książki te nie wracały już na swoje miejsce. Tym samym rozpoczął się powolny, ale ustawiczny proces rozpraszania pojezuickiego księgozbioru ${ }^{97}$. Po

\footnotetext{
${ }^{96}$ J. Rulikowski, Urywek wspomnień Józefa Rulikowskiego wydany z obszerniejszego rękopisu (1731-1789), Warszawa 1862, s. 187-188.

${ }^{97}$ Por. Zalewski, Biblioteka, k. 219. Autor w tym miejscu przytacza pracę R. Kotuli (Wtaściciele rękopisów i starodruków zbiorów wielkopolskich Czarnieckiego, mieszczace się obecnie w Baworowianum we Lwowie, Lwów 1924 s. 18) oraz opis katedry lubelskiej ks. Boniewskiego: „Za kapitularzem jest miejsce na skład sprzętu kościelnego przeznaczone, a $\mathrm{z}$ tego powodu schody do Biblioteki, gdzie w szafach dużych mieści się mały zbiór książek po większej części z jezuickiego zbioru. Najważniejsze z dzieł, jakie zawiera jest kollekcja pism Ojców Kościoła”. Ks. Zalewski uważa, że wiadomość ta nie jest w pełni wiarygodna, bowiem w kapitularzu istotnie była część książek po jezuitach, ale większość pochodziła po kanonikach z Krasnegostawu. Książki te następnie bp M. Fulman oddał do Biblioteki „Bobolanum” w Lublinie.
} 
roku pracy nad porządkowaniem biblioteki stwierdzono, że „mimo wielkiej usilności i z nadwyrężeniem zdrowia" porządkowania nie ukończono ${ }^{98}$. Czynności te nie zostały wówczas, ani też później zakończone. O rezultatach tych prac zresztą nic bliższego nie wiadomo. $Z$ każdym rokiem stan budynków dawnego kolegium pogarszał się, a wraz z nim i sytuacja biblioteki. W końcu doszło do zawalenia się stropu i przysypania gruzem znajdujących się książek. Po wydobyciu z gruzowiska woluminów, w 1818 r. ponownie postanowiono o sporządzeniu ich konsygnacji. Delegowani do załatwienia tej sprawy komisarze uznali,

iż uporządkowanie tych książek na kupę zwalonych długiego czasu wymaga, przeto nie mogąc się zająć spisaniem takowych, wezwali J. X. Administratora, aby katalog książek z gruzów wydobytych spisał i takowy swego czasu dodatkowo Komisji województwa lubelskiego celem dołączenia do niniejszego dzieła (tj. tomu) przedstawić starał się

W Lublinie, zgodnie z zaleceniem KEN, część zbiorów pojezuickich znalazła się w bibliotece szkolnej. Po III rozbiorze Polski, szkoła mieszcząca się $\mathrm{w}$ gmachu dawnych szkół jezuickich została przekształcona w gimnazjum austriackie, a po $1811 \mathrm{r}$. funkcjonowała jako szkoła departamentowa. Jej rektor, Andrzej Smolikowski, jako pilną potrzebę widział wyposażenie szkoły w bibliotekę, gdyż obejmując placówkę zastał w niej, obok pojedynczej książki pedagogicznej, zbiory pojezuickie, a właściwie ich fragmenty. Jak podaje Mieczysława Adrianek, pojezuicki księgozbiór znajdujący się w szkole liczył około 500 nieuporządkowanych i będących w złym stanie książek ${ }^{100}$. W raporcie wizytatora Izby Edukacyjnej odwiedzającego szkołę w $1810 \mathrm{r}$. znalazła się uwaga o stosie zbutwiałych ksiąg, „które z gruzów zawalonej biblioteki po jezuitach wydobyto, nic się tu zachowania godnego nie znajduje"101. Pomnażanie szkolnego księgozbioru postępowało sprawnie dzięki zaradności A. Smolikowskiego i ofiarności społecznej.

${ }^{98}$ Zalewski, Biblioteka, k. 218. Autor powołuje się za Z. Kukulskim (Pierwsi nauczyciele świeccy) na raporty wizytatorów generalnych, wysłanych przez Szkołę Główną Koronną, w których znajdują się informacje o bibliotece jezuickiej. W 1785 r. wizytator Bobucicki pisał, że biblioteka jeszcze nie jest uporządkowana, ponieważ ma być przeniesiona do nowego domu, i że „wielkie mnóstwo znajduje się książek i po części spleśniałych, dla suszenia więc przewietrzania, a potem przeniesienia onychże, co się nie obejdzie bez znacznego kosztu, uprasza zgromadzenie na ten koniec przyzwoitej kwoty". Z kolei w 1790 r. wizytator Jan Kanty Krusiński informował, że biblioteka dotąd nie została ułożona „mimo wielkiej usilności i z nadwyrężeniem zdrowia podjętej już pracy J. Ks. Wędykowskiego prefekta razem z J. Ks. Zaleskim profesorem Klasy II”.

${ }^{99}$ Zalewski, Biblioteka, k. 219. Cytowany ustęp jest częścią opisu „dawnego funduszu” trynitarskiego, wykonanego przez delegatów biskupich 1818 r. Były to jednak raczej resztki biblioteki pojezuickiej. Biblioteka bowiem trynitarzów licząca według katalogu z 1792 r. 325 dzieł w 436 tomach nie wymagałaby „długiego czasu” na katalogowanie. Trudno również zgodzić się, że trynitarze dopuścili się przysypania gruzem własnej biblioteki. O bibliotece trynitarzy zob. Zalewski, Biblioteka seminarium, s. $246 \mathrm{nn}$.

${ }^{100}$ Wełna-Adrianek, Początki bibliotekarstwa, s. 704; H. Wolska, Księgozbiór Gimnazjum Lubelskiego, „Bibliotekarz Lubelski”, 27 (1982) s. 13.

${ }^{101}$ A. Karbowiak, Wizyta szkót gimnazjalnych $w$ czterech nowych departamentach Księstwa Warszawskiego w r. 1810, „Archiwum do dziejów Literatury i Oświaty w Polsce”, 1904, t. 10, s. 139. 
Trzeba dodać, że do szkoły w 1813 r. trafił ponadto księgozbiór powołanego dwa lata wcześniej Instytutu Bibliopolicznego, który dzięki darom indywidualnym i inicjatywom miejscowych drukarzy szybko stał się znaczącą kolekcją ${ }^{102}$. W 1817 r. rozpoczęto porządkowanie biblioteki szkolnej i zainicjowano opracowanie inwentarza oraz katalogu. W chwili przejścia A. Smolikowskiego na emeryturę w 1828 r. biblioteka liczyła ponad 5.000 woluminów ${ }^{103}$.

Po powstaniu listopadowym, sytuacja szkoły i biblioteki stała się trudniejsza. Zniknęły dary - ostatni zanotowano w 1834 r. Uzupełnianiem i zakupami zajmowano się centralnie przede wszystkim poprzez Biblioteką Rządową (uniwersytecką) w Warszawie, pełniącej rolę biblioteki Okręgu Naukowego Warszawskiego. Trzeba przypomnieć, że w Okręgu Naukowym Warszawskim powstałym w 1840 r. od lat 50. XIX wieku działał komitet do spraw bibliotek. Lubelska biblioteka szkolna mieszcząca się w gmachu szkoły, pozostawała zaniedbana do lat 50. XIX stulecia. Dopiero wybudowanie nowego gmachu szkoły radykalnie zmieniło sytuację lokalową. Trzeba dodać, że w 1851 r. dyrektorem szkoły został Józef Skłodowski i za jego rządów sytuacja biblioteki poprawiła się, a nawet opracowany został katalog i przeprowadzone prace konserwatorskie. Biblioteka nie została od razu przeniesiona do nowego gmachu szkolnego i przez pewien czas pozostawała w starych pomieszczeniach (urządzono tam koszary). W momencie przenosin na ul. Namiestnikowską, ze zbioru liczącego ok. 10.000 ubyło „nieco” (nie wiadomo ile) książek ${ }^{104}$.

Od 1867 r. szkoła została przekształcona w gimnazjum rosyjskie. Księgozbiór biblioteki został podzielony na dwa działy: nauczycieli i uczniowski, a nadzór nad biblioteką pełnili nauczyciele rosyjscy. Głównym ich celem była rusyfikacja zbiorów. Dopiero po objęciu funkcji bibliotekarza w 1899 r. przez Hieronima Łopacińskiego, profesora języków klasycznych, zmieniło się podejście do księgozbioru. H. Łopaciński cenił zabytkową bibliotekę, planował prace historyczne nad księgozbiorem, ale tragiczna śmierć uniemożliwiła mu realizację zamierzeń. Ciekawsze obiekty biblioteczne prezentował na lubelskiej wystawie sztuk i starożytności w 1901 r., ale nie wiadomo czy wśród nich znalazły się obiekty ze zbiorów pojezuickich ${ }^{105}$. W okresie I wojny światowej biblioteka pozostawała bez opieki. Stanisław Tomkiewicz autor książki Wycieczka w Lubelskie wydanej w 1916 r. pisał:

Biblioteka gimnazjalna powstała ze zbiorów dawnych szkół wojewódzkich.

Zapewne włączono niegdyś do nich także księgozbiory klasztorne prywatne. Tem thumaczymy sobie okoliczność, że spotykamy tutaj również wiele rzadkich i starych druków nie nadających się bynajmniej do celów szkolnych. [...]. Książki mieszczą się w szafach, w jakim takim porządku i w miejscu zamknię-

${ }_{102}$ M. Wełna-Adrianek, Instytut Bibliopoliczny - pierwsza biblioteka publiczna $w$ Lublinie (1811-1813), „Roczniki Biblioteczne”, 12 (1968) s. 199-221.

103 Taż, Początki bibliotekarstwa, s. 705.

${ }^{104}$ Wolska, Księgozbiór Gimnazjum Lubelskiego, s. 14.

${ }^{105}$ Wełna-Adrianek, Poczatki bibliotekarstwa, s. 707. 
tym a suchym, ale opróżniając dla wojska gmachy zniesiono do sal bibliotecznych sprzęty i graty $\mathrm{z}$ sal innych czyniąc istne rupieciarnie ${ }^{106}$.

Biblioteką zainteresował się również prezes Komitetu Biblioteki im. H. Łopacińskiego, dr Jaworowski. W obawie, że Rosjanie mogą wrócić po wycofaniu się z Lublina w 1915 r., starał się on cenniejsze dzieła polskie, pochodzące przeważnie z dawnej biblioteki jezuickiej, wydzielić i włączyć do Publicznej Biblioteki im. H. Łopacińskiego. Dla zatarcia śladów, wycinał stemple rosyjskie, a razem z nimi często niszczył i dawniejsze odręczne napisy jezuickie „Coll. Lublin S. J.” oraz pieczątki tuszowe „z Biblioteki szkoły wojewódzkiej Lubelskiej”. W ten sposób na wielu książkach powstał brak wcześniejszego dowodu ich pochodzenia. Zostały ślady wycięcia oraz zaklejania dla uzupełnienia karty tytułowej. Księgozbiór w 1919 r. został przekazany do biblioteki im. Lopacińskiego, ale faktycznie nie włączono go do zbiorów, lecz pozostawał w piwnicy gimnazjum im. S. Staszica. Według Edwarda Chwalewika, w bibliotece gimnazjum część starszych książek pochodziła z księgozbioru dawnych szkół, m.in. po jezuitach lubelskich ${ }^{107}$. Jak podawał Kazimierz Jaczewski w sprawozdaniu pt. Pierwsze ćwierćwiecze Biblioteki publicznej im. H. Lopacińskiego w Lublinie, książki faktycznie pozostawały w piwnicy gimnazjum im. S. Staszica do 1933 r., a później w pomieszczeniach Syndykatu Rolniczego. Powodem takiego przechowywania był zapewne zły stan księgozbioru. Książki umieszczone w szkolnej piwnicy, zostały zaatakowane przez korniki i mimo przeniesienia na wiosnę 1939 r. całej biblioteki do nowego budynku przy ul. Narutowicza, wspomniane zbiory pozostały na miejscu celem przejrzenia i prawdopodobnie konserwacji, czego jednak nie zdążono zrobić przed wybuchem wojny ${ }^{108}$.

Podczas okupacji, Niemcy przekazali zbiór do Biblioteki KUL, gdzie był przechowywany do 1948 r., a następnie jako część księgozbioru Biblioteki im. H. Łopacińskiego został przekazany przez Towarzystwo tej Biblioteki, Zarządowi Miasta Lublina. W latach 50. XX wieku trafił do gmachu Wojewódzkiej Biblioteki Publicznej im. Hieronima Łopacińskiego w Lublinie przy ul. Narutowicza i prowizorycznie został skatalogowany. Dopiero w 1979 r. w Dziale Gromadzenia i Opracowania Zbiorów podjęto systematyczne działania nad opracowaniem księgozbioru gimnazjalnego, należącego do wspomnianej biblioteki formalnie od 1919 r. Cały księgozbiór gimnazjalny liczy ok. 5.200 tomów, z czego na starodruki przypada 400 pozycji.

$\mathrm{Na}$ podstawie opracowanego katalogu proweniencji można stwierdzić, że wśród zachowanych starodruków stosunkowo liczne są książki pochodzące $\mathrm{z}$ kolegium lubelskiego, w porównaniu z drukami o innym pochodzeniu ${ }^{109}$. W tej chwili odnotowane są 94 tytuły posiadające proweniencję kolegium lubelskiego

${ }^{106}$ Za: Wolska, Księgozbiór Gimnazjum Lubelskiego, s. 15.

${ }^{107}$ E. Chwalewik, Zbiory polskie, t. 1, Warszawa 1926, s. 354.

${ }^{108}$ Wolska, Księgozbiór Gimnazjum Lubelskiego, s. 15-16.

${ }^{109}$ Niezależnie od dróg wędrówki odnotowanych egzemplarzy, do WBPHŁ trafiły książki, w liczbie od jednego do kilkunastu egzemplarzy, pochodzące $\mathrm{z}$ różnych ośrodków jezuickich, m.in. z Kalisza, Brześcia, Bydgoszczy, Warszawy, Insbrucka, Wiednia (15) i odległego monasteru w Coimbra w Portugalii. 
i jeden druk pochodzący z „Bobolanum”. Katalog dobrze ukazuje przemieszanie i losy ksiąg należących do jezuitów, chociaż dopiero szczegółowe prześledzenie proweniencji być może pozwoliłoby na kompletne ustalenie dróg nabycia/ wpłynięcia poszczególnych tomów do księgozbioru. O przynależności poszczególnych tomów do kolegium świadczą odręczne noty proweniencyjne, głównie w brzmieniu „Inscriptus Catalogo Libror. Coll. Lubl. Soc. Jesu”. Napis w wielu tomach jest częściowo zamazany, skreślony lub wytarty, jednak możliwe było jego odczytanie. Ponadto dobrze widoczne są pieczątki owalne Szkoły Wojewódzkiej Lubelskiej i wycięte miejsca po znakach własnościowych gimnazjum rosyjskiego. W świetle katalogu, w ujęciu chronologicznym, w zbiorach pojezuickich znajduje się sześć inkunabułów, a niemal połowa bo 45 zachowanych druków, pochodzi z XVI wieku, 37 ksiąg zostało wytłoczonych w XVII w., a sześć tytułów wydano w XVIII stuleciu. Druki pochodzą z oficyn znanych europejskich ośrodków sztuki typograficznej: m.in. Wenecji, Bazylei, Kolonii, Antwerpii, Strasburga i Paryża. W zbiorach są także druki tłoczone w ośrodkach krajowych, w typografiach krakowskich, w tym w oficynie Siebeneycherów, Łazarza, Schedeliana, ponadto w zakładach Wilna, Zamościa oraz typografiach jezuickich w Kaliszu, Poznaniu i Lublinie ${ }^{110}$.

Pomimo znaczenia bibliotek szkolnych dla zachowania księgozbioru pojezuickiego trzeba stwierdzić, że przechowały one tylko mniejszy fragment tego zbioru. Większa część biblioteki jezuickiej licząca ok. 3.000 tomów jeszcze w latach 20. XX wieku znajdowała się w katedrze lubelskiej, złożona na piętrze obok wielkiego ołtarza. Były to głównie książki o tematyce teologicznej i z zakresu prawa kościelnego. $Z$ uwagi na trudne losy i brak właściwych warunków przechowywania, część książek była zniszczona ${ }^{111}$.

Książki złożone w katedrze pochodzą zapewne z tej części biblioteki pojezuickiej, której nie udało się uporządkować i skatalogować lub chociażby spisać. W celu ich prowizorycznego zabezpieczenia, po rozebraniu w latach 1815-1818 południowego i zachodniego skrzydła kolegium, książki umieszczono w dawnym kościele jezuickim. Przez ponad sto lat nie były obiektem zainteresowania, tym bardziej, że nie były dostępne. Dopiero przeniesienie do Lublina z Krakowa w 1926 r. jezuickiego studium teologii „Bobolanum” stworzyło warunki do przywrócenia do życia zapomnianej części biblioteki pojezuickiej ${ }^{112}$. W czasie działalności Wydziału Teologicznego „Bobolanum” w Lublinie, starodruki złożone w katedrze lubelskiej zostały włączone do zbiorów biblioteki uczelnianej, w której znajdują się do dnia dzisiejszego ${ }^{113}$. Została ona wraz z wydziałem teologicznym przeniesiona w sierpniu 1952 r. z Lublina do Warszawy.

${ }^{110}$ Obecnie druki są w dobrym stanie, część z nich ostatnio została poddana konserwacji.

${ }^{111}$ Chwalewik, Zbiory polskie, s. 354.

${ }^{112}$ L. Grzebień, Wydział Teologiczny „Bobolanum” w Lublinie (1926-1939), w: Dzieje Lubelszczyzny, t. 5, red. T. Mencel, Warszawa 1986, s. 205-207.

${ }^{113}$ Polonica z XVI w. z biblioteki jezuitów lubelskich przechowywane obecnie w „Bobolanum” zestawił L. Grzebień, Katalog starych druków, numery: 7, 20, 36, 39, 41, 59, 66, 71, 76, 100, 115. O dziejach Biblioteki Teologicznej „Bobolanum” zob. W.W. Żurek, Biblioteki Kościoła Katolickiego w Polsce. Informator, Kielce 2005 s. 57-58. 
Powyższe ustalenia ukazują złożoność badań nad dziejami jednej z większych bibliotek lubelskich należących do jezuitów. W świetle dostępnych źródeł należy stwierdzić, że ta bogata biblioteka podzieliła los wielu księgozbiorów zgromadzonych przez zakony, ulegając rozproszeniu. Niemniej, rekonstrukcja losów biblioteki pozwala stwierdzić, iż przynajmniej pewna jej część, mimo niepomyślnych dziejów, dotrwała do czasów współczesnych. Dziś książki z lubelskiego kolegium jezuitów są przechowywane w różnych bibliotekach w całej Polsce. Największe zbiory posiadają Biblioteka „Bobolanum” w Warszawie i Wojewódzka Biblioteka Publiczna im. Hieronima Łopacińskiego w Lublinie, ale lista bibliotek jest dłuższa, znajdują się na niej m.in. Biblioteka Metropolitalnego Seminarium Duchownego w Lublinie, Biblioteka Narodowa w Warszawie, Biblioteka Zakładu Narodowego im. Ossolińskich we Wrocławiu. Niewątpliwie w tej sytuacji konieczne jest podjęcie kompleksowych prac inwentaryzacyjnych, nieodzowne są także badania proweniencyjne zachowanych egzemplarzy.

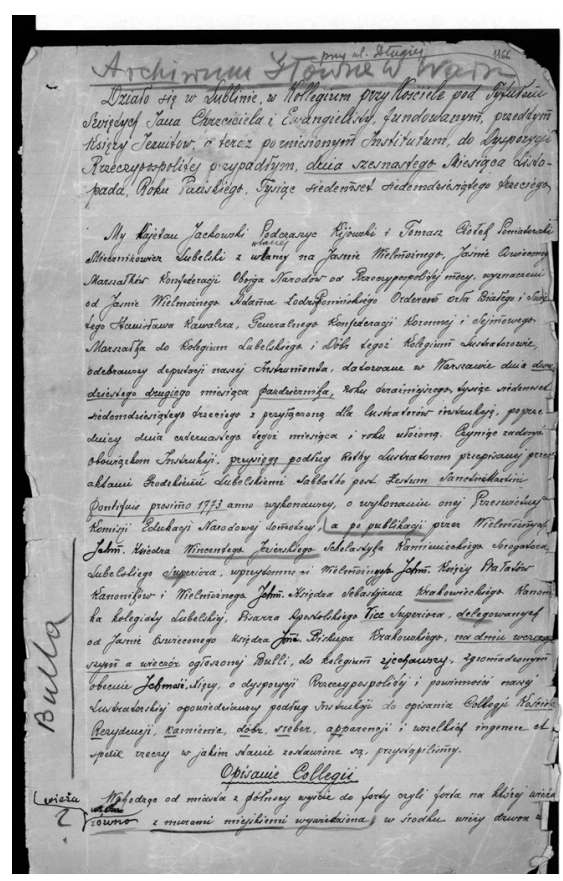

1. Lustratio Ecclesiae collegii Lublinensis S. I. - pierwsza strona odpisu (rkps, WBPHŁ, sygn. 2160 IV, k. 1166). 


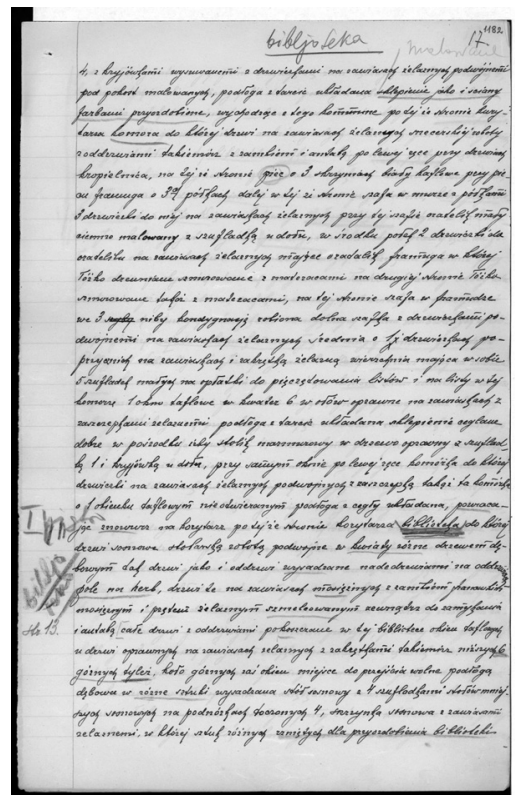

2. Lustratio Ecclesiae collegii Lublinensis S. I. - początek opisu biblioteki (rkps, WBPHŁ, sygn. 2160 IV, k. 1182).

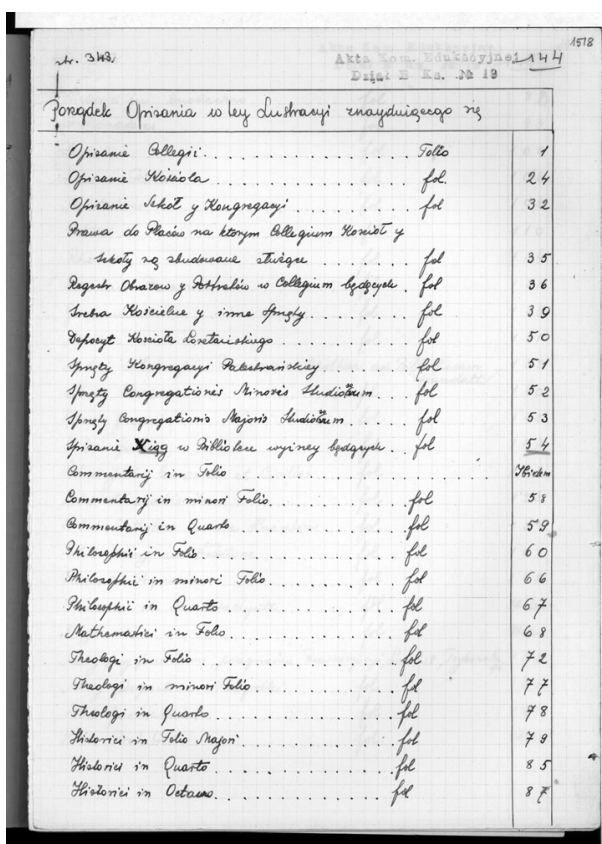

3. Lustratio Ecclesiae collegii Lublinensis S. I. - spis zawartości dotyczący biblioteki (rkps, WBPHŁ, sygn. 2160 IV, k. 1518). 


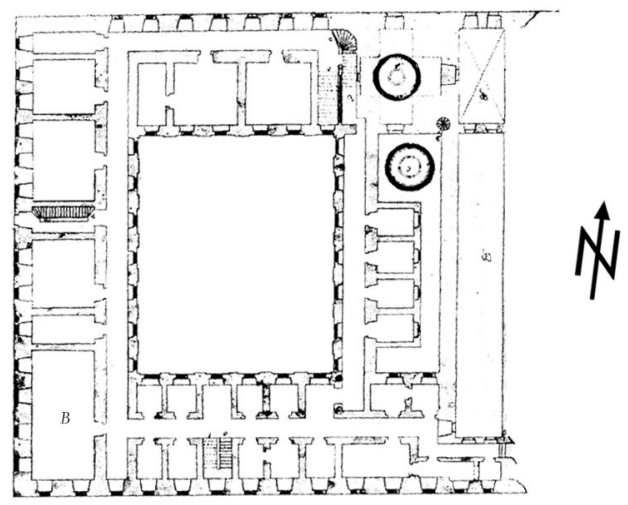

II pietro

4. Pomieszczenie biblioteki (B) na planie 2. piętra kolegium (na podstawie:

L. Zalewski, Katedra i jezuici w Lublinie, cz. 1, s. 69).

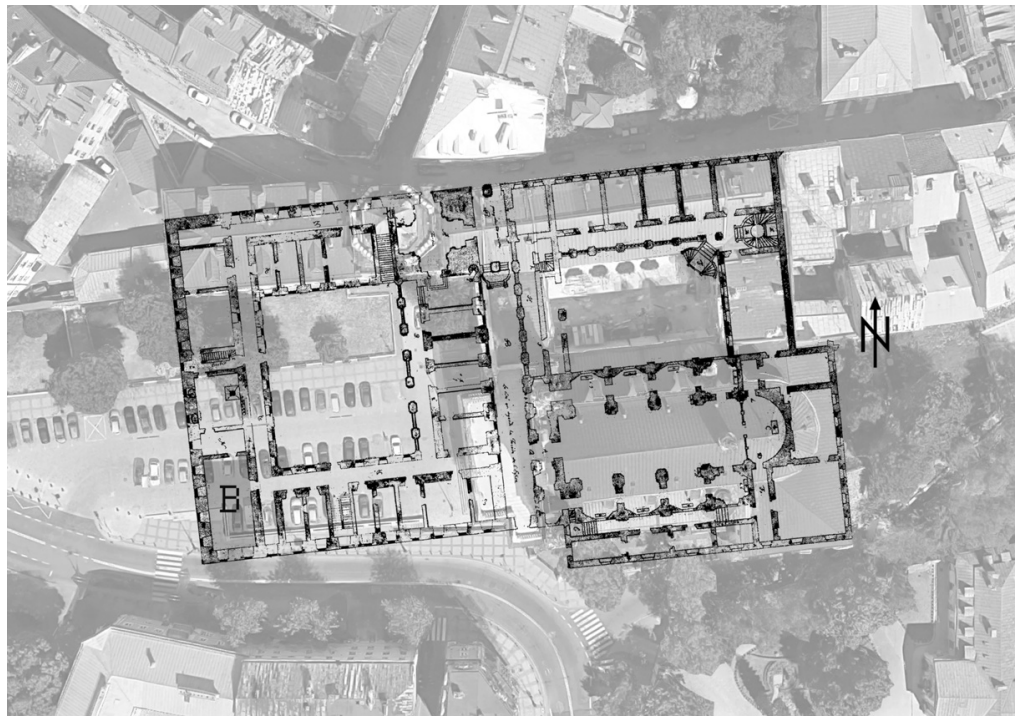

5. Orientacyjny rzut kolegium jezuickiego na ortofotomapie Lublina z placem katedralnym, z zaznaczonym miejscem biblioteki - (B). 


\section{BIBLIOGRAFIA}

Bednarski Stanisław, Upadek i odrodzenie szkół jezuickich w Polsce. Studium z dziejów kultury i szkolnictwa polskiego, Kraków 1933 (repr. Wydawnictwo WAM, Kraków 2003).

Bieś Andrzej Paweł, Podstawowa bibliografia jezuickich bibliotek w Polsce, w: Librorum amatori. Księga pamiątkowa ofiarowana ks. Czesławowi Michalunio SJ na 50-lecie ofiarnej pracy w Bibliotece Filozoficznej Towarzystwa Jezusowego w Krakowie, red. Andrzej Paweł Bieś SJ, Kraków 2004, s. 193-200.

Chwalewik Edward, Zbiory polskie, t. 1, Warszawa 1926.

Dobrzański Jan, Lubelska szkoła Komisji Edukacji Narodowej, w: Ze studiów nad Komisja Edukacji Narodowej i szkolnictwem na Lubelszczyźnie. Rozprawy i artykuły, red. Jan Dobrzański, Albin Koprukowniak, Lublin 1973, s. 259-291.

Dziok-Strelnikowa Irena, Bibliografia starych druków lubelskich 1630-1800, Lublin 1997. Graczyk Waldemar, Kwiatkowski Jarosław, Jezuici w Płocku 1611-1773, Warszawa 2002. Grzebień Ludwik, Biblioteki jezuickie w Krakowie od XVI do XVIII wieku, w: Librorum amatori. Księga pamiątkowa ofiarowana ks. Czesławowi Michalunio SJ na 50-lecie ofiarnej pracy w Bibliotece Filozoficznej Towarzystwa Jezusowego w Krakowie, red. Andrzej Paweł Bieś SJ, Kraków 2004, s. 29-55.

Grzebień Ludwik, Dzieje kulturalne jezuitów toruńskich (1596-1996), w: Jezuici w Toruniu 1596-1996, red. Kazimierz Maliszewski, Waldemar Rozynkowski, Toruń 1997, s. $55-83$.

Grzebień Ludwik, Józef Andrzej Załuski a jezuici, „Roczniki Teologiczno-Kanoniczne”, 31 (1984) z. 4, s. 55-70.

Grzebień Ludwik, Katalog starych druków biblioteki teologicznej Bobolanum (Polonica XVI w.), „Archiwa, Biblioteki i Muzea Kościelne”, 16 (1968) s. 243-278.

Grzebień Ludwik, Organizacja bibliotek jezuickich w Polsce od XVI do XVIII wieku, Kraków 2013.

Grzebień Ludwik, Wydziat Teologiczny „Bobolanum” w Lublinie (1926-1939), w: Dzieje Lubelszczyzny, t. 5, red. Tadeusz Mencel, Warszawa 1986, s. 189-209.

Katalog rękopisów Biblioteki Narodowej, t. 7, red. Krystyna Muszyńska, Warszawa 1969.

Kempa Andrzej, Losy jezuickich księgozbiorów, „Bibliotekarz”, 9 (2009) s. 29.

Kochanowicz Piotr, Inwentarze bibliotek jezuickich 1570-1820. Próba rekonstrukcji, w: Librorum amatori. Ksiega pamiatkowa ofiarowana ks. Czesławowi Michalunio SJ na 50-lecie ofiarnej pracy w Bibliotece Filozoficznej Towarzystwa Jezusowego w Krakowie, red. Andrzej Paweł Bieś SJ, Kraków 2004, s. 163-178.

Kościelak Sławomir, Jezuici w Gdańsku od drugiej połowy XVI do końca XVIII wieku, Kraków 2003.

Kozerska Helena, Straty $w$ zbiorze rękopisów Biblioteki Uniwersyteckiej $w$ Warszawie w czasie I i II wojny światowej, Warszawa 1960.

Kukulski Zygmunt, Obrady zgromadzeń akademickich Wydziału Małopolskiego w Lublinie w 1790 r., Lwów 1923.

Lisiak Bogdan, Proces przed Trybunatem Lubelskim w sprawie ksiażek Potockiego w bibliotece jezuitów lubelskich, w: Librorum amatori. Księga pamiątkowa ofiarowana ks. Czesławowi Michalunio SJ na 50-lecie ofiarnej pracy w Bibliotece Filozoficznej Towarzystwa Jezusowego w Krakowie, red. Andrzej Paweł Bieś SJ, Kraków 2004, s. $127-131$.

Majorek Czesław, Książki szkolne Komisji Edukacji Narodowej, Warszawa 1995. 
Niesiecki Kasper, List Kaspra Niesieckiego SJ do Józefa Andrzeja Załuskiego, w: Librorum amatori. Ksiega pamiatkowa ofiarowana ks. Czestawowi Michalunio SJ na 50-lecie ofiarnej pracy w Bibliotece Filozoficznej Towarzystwa Jezusowego w Krakowie, red. Andrzej Paweł Bieś SJ, Kraków 2004, s. 133-135.

Paszenda Jerzy, Pomieszczenia biblioteczne u jezuitów polskich, w: Librorum amatori. Księga pamiatkowa ofiarowana ks. Czestawowi Michalunio SJ na 50-lecie ofiarnej pracy w Bibliotece Filozoficznej Towarzystwa Jezusowego w Krakowie, red. Andrzej Paweł Bieś SJ, Kraków 2004, s. 111-118.

Piechnik Ludwik, Powstanie i rozwój jezuickiej „,Ratio studiorum” (1548-1599), Kraków 2003.

Piechnik Ludwik, ,, Ratio studiorum ”: fundament działalności edukacyjnej i naukowej jezuitów, w: Wkład jezuitów do nauki i kultury w Rzeczypospolitej Obojga Narodów i pod zaborami, red. Irena Stasiewicz-Jasiuk, Kraków-Warszawa 2004, s. 69-90.

Piechnik Ludwik, Seminaria diecezjalne w Polsce prowadzone przez jezuitów od XVI do XVIII wieku, Kraków 2001.

Rudnicka Jadwiga, Biblioteka Wilanowska. Dwieście lat jej dziejów (1741-1932), Warszawa 1967.

Rulikowski Józef, Urywek wspomnień Józefa Rulikowskiego wydany z obszerniejszego rękopisu (1731-1789), Warszawa 1862.

Sułek Anna, Ekslibris i superekslibris XVIII w. w zbiorach Biblioteki Metropolitalnego Seminarium Duchownego w Lublinie, „Bibliotekarz Lubelski”, 41 (1996) s. 27-34.

Wełna-Adrianek Mieczysława, Instytut Bibliopoliczny - pierwsza biblioteka publiczna w Lublinie (1811-1813), „Roczniki Biblioteczne”, 12 (1968) s. 199-222.

Wełna-Adrianek Mieczysława, Poczatki bibliotekarstwa publicznego w Lublinie, „Roczniki Biblioteczne", 14 (1970) z. 3/4, s. 703-724.

Wolska Halina, Księgozbiór Gimnazjum Lubelskiego, „Bibliotekarz Lubelski”, 27 (1982) s. 13-19.

Zalewski Ludwik, Biblioteka seminarium duchownego w Lublinie i biblioteki klasztorne $w$ diecezji lubelskiej i podlaskiej, Warszawa 1926.

Zalewski Ludwik, Katedra i jezuici w Lublinie, cz. 1, Lublin 1947.

Zalewski Ludwik, Orlęta lubelskie. Nauka, wychowanie i życie młodzieży męskiej w Lublinie 1586-1773, Lublin 1947.

Żukowska Ewa Anna, Powstanie i działalność drukarni jezuickiej w Lublinie, w: Lublin a ksiażka, cz. 2: Centrum i peryferie, red. A. Krawczyk, Lublin 2011, s. 237-244.

Żurek Waldemar Witold, Biblioteki Kościoła Katolickiego w Polsce. Informator, Kielce 2005. 


\section{BIBLIOTEKA KOLEGIUM JEZUITÓW W LUBLINIE I JEJ LOSY}

\section{Streszczenie}

Biblioteka kolegium jezuitów w Lublinie powstała w 1584 r. Sukcesywnie powiększana darami, zakupami, twórczością jezuitów i produkcją własnej drukarni liczyła w chwili kasaty zakonu 5.000-7.000 dzieł. Należała do grupy największych bibliotek jezuickich w Polsce. Znajdowały się w niej dzieła teologiczne, filozoficzne, historyczne, matematyczne, ponadto polityczne, prawne, do nauki szkolnej, medyczne, traktaty polemiczne, zbiory kazań i mów. W kolegium lubelskim działały różne rodzaje bibliotek. Najważniejszą, dostępna dla braci zakonnych, była biblioteka domowa, zwana też wspólną. Oprócz niej istniały biblioteki i księgozbiory związane z pełnieniem urzędów i funkcji, zwane specjalnymi lub specjalistycznymi. Można stwierdzić, że w Lublinie było co najmniej 12 bibliotek specjalnych. Do połowy XVIII w. biblioteka jezuitów lubelskich specjalnie się nie wyróżniała spośród innych domów zakonnych, dopiero w połowie tego stulecia została odnowiona i ozdobiona sala biblioteki wspólnej. Dzięki temu nabrała ozdobnego charakteru, wzbudzając tym podziw oglądających. Uporządkowano też zapewne księgozbiór w ramach działów przedmiotowych. Niestety nie zachowały się dawne katalogi, $\mathrm{o}$ istnieniu których wiadomo z not własnościowych.

Po kasacie zakonu jezuitów lubelska biblioteka nie wzbudzała większego zainteresowania, chociaż decyzją KEN powinna zasilić księgozbiory szkolne. Powolnej degradacji ulegał budynek biblioteki, księgozbiór, jako mało przydatny pozostawał w nieładzie. Jednak część zbiorów (prawdopodobnie ok. 500 książek) znalazło się w bibliotece szkoły powstałej w miejsce kolegium jezuickiego i dzieliło losy szkolnego księgozbioru. W roku 1919 księgozbiór po gimnazjum lubelskim przekazany został do Biblioteki im. Hieronima Łopacińskiego, chociaż faktycznie trafił tam dopiero po II wojnie światowej. Obecnie według katalogu w zbiorach specjalnych Biblioteki Wojewódzkiej im. H. Łopacińskiego znajdują się 94 druki pochodzące z biblioteki pojezuickiej. Znaczna część zbiorów, bo ok. 3.000 tomów została złożona w katedrze i w chwili przeniesienia „Bobolanum” do Lublina w okresie międzywojennym, została włączona do jej biblioteki.

Słowa kluczowe: Jezuici; kolegium jezuitów; biblioteka jezuitów; Lublin 


\title{
THE LIBRARY OF \\ THE JESUIT COLLEGE IN LUBLIN AND ITS HISTORY
}

\begin{abstract}
Summary
The Library of the Jesuit College in Lublin was established in 1584 . The collection successively increased thanks to gifts, purchases, Jesuit works and publications from its own printing house. At the time of the dissolution of the order, it included 5.000-7.000 works. It was one of the largest Jesuit libraries in Poland. It contained theological, philosophical, historical, mathematical, political, legal and medical works; school textbooks; polemical treatises; collections of sermons and talks. There were various types of libraries in the college of Lublin. The most important one, available to monks, was a home library (also called a common library). In addition, there were libraries and book collections related to different offices and functions; they were called special or specialized. There were at least 12 special libraries in Lublin. At first, the Library of the Lublin Jesuits was not particularly distinguished from other religious houses. However, in the middle of the 18th century, the common library hall was renovated and decorated. Thanks to this, it acquired a decorative character, arousing the admiration of visitors. The book collection was probably also arranged in subject sections. Unfortunately, the old catalogues have not survived, and we know about their existence from bookplates.

After the dissolution of the Jesuits, the Library of Lublin did not attract much interest, although the Commission of National Education decided that the collection should be transferred to school libraries. Both the building of the library and the collection gradually deteriorated. However, some books of the collection (probably around 500) were placed in the library of the primary school established in the former Jesuit College. In 1919, the collection of the Jesuit Library was donated to Hieronim Łopaciński Library, although it was not transferred there until after World War II. Currently, according to the catalogue, in the special collections of the Provincial Library, there are 94 books from the Jesuit Library. A large part of the collection - about 3.000 volumes - was deposited in the cathedral, and at the time of transferring „Bobolanum” to Lublin in the interwar period, it was incorporated into the Bobolanum Library.
\end{abstract}

Keywords: the Jesuits; the Jesuit College; the Jesuit Library; Lublin 